2007

Solving the Contentious Issues of Private Conservation Easements: Promoting Flexibility for the Future and Engaging the Public Land Use Process

Gerald Korngold

New York Law School

Follow this and additional works at: http://digitalcommons.nyls.edu/fac_articles_chapters

Part of the Housing Law Commons, Land Use Law Commons, Property Law and Real Estate Commons, and the Tax Law Commons

Recommended Citation

2007 Utah Law Review 1039

This Article is brought to you for free and open access by the Faculty Scholarship at DigitalCommons@NYLS. It has been accepted for inclusion in Articles \& Chapters by an authorized administrator of DigitalCommons@NYLS. 


\title{
Solving THE Contentious IsSues of PRIVATE Conservation EASEMENTS: PROMOTING FLEXIBILITY FOR THE FUTURE AND Engaging the Public Land Use Process
}

\author{
Gerald Korngold*
}

Over the past thirty years, statutes have reversed the common law and authorized private conservation organizations to hold conservation easements in gross. These interests allow nonprofits to control the use and development of the burdened property by preventing alterations of the natural and ecological features. Conservation easements can be held by organizations geographically distant from the restricted land.

Conservation easements bring great benefits as they support conservation, represent private initiative, yield efficiency benefits, and exemplify freedom of choice of property owners. But there are also costs: significant federal and state tax subsidies, the lack of coordinated planning and public process, class issues, stewardship failures by nonprofits, and lack of flexibility by easement holders to meet emerging needs of the community (such as for economic development or affordable housing). Further, there is a risk to effective policy making and democratic principles when local public land use decisions are delegated to nonrepresentative, nonaccountable private organizations.

The benefits of private conservation easements are significant, and they should be continued but with changes. This Article suggests five principles and related specific reforms that should be enacted: restoring market mechanisms in the creation of conservation easements, enhancing governance and operations of easement holders, protecting the expectations of future generation owners, achieving flexibility through expanded termination and modification doctrines, and preserving the public's power of eminent domain.

* (C) 2008 by Gerald Korngold, Everett D. and Eugenia S. McCurdy Professor of Law, Case Western Reserve University of Law and Visiting Fellow, Lincoln Institute of Land Policy, Cambridge, Massachusetts. The author appreciates comments from participants at faculty workshops at New York Law School, Brooklyn Law School, and Villanova University School of Law, as well as detailed comments from Jonathan Adler. All errors and opinions are, of course, the author's alone. 


\section{TABLE OF CONTENTS}

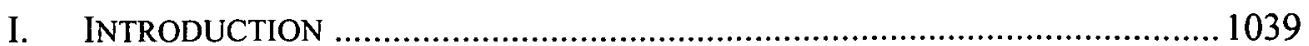

II. THE ORIGINS AND DEVELOPMENT OF CONSERVATION EASEMENTS.......... 1044

A. Defining Conservation Easements .................................................. 1044

B. The Growth in Conservation Easements .......................................... 1046

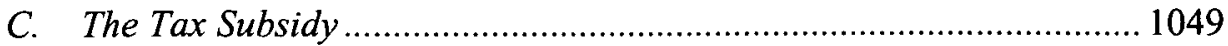

D. Perpetuity and In Gross Ownership.............................................1050

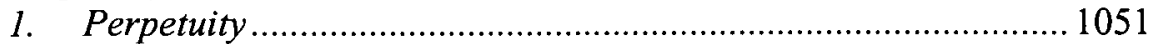

2. In Gross Ownership .............................................................. 1051

3. Covenants, Easements, and Property Theory ............................ 1052

III. The POLICY MATRIX: THE ADVANTAGES AND CONCERNS WITH

PRIVATE CONSERVATION EASEMENTS ……………….............................. 1054

A. Advantages of Conservation Easements ........................................... 1054

1. The Conservation Value ......................................................... 1054

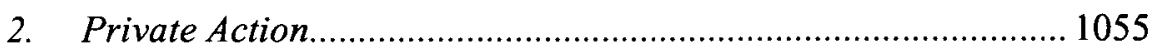

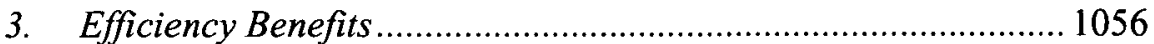

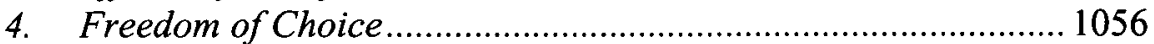

B. Concerns About Conservation Easements ........................................ 1057

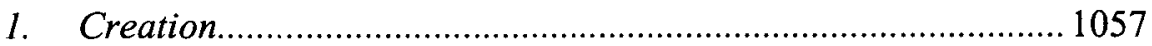

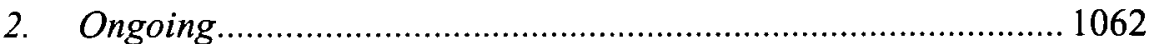

IV. FIVE PRINCIPLES FOR IMPROVING THE LAW OF CONSERVATION

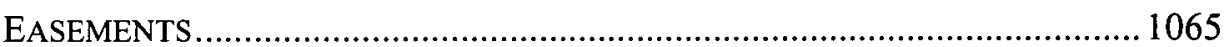

A. Principle I: Restore Market Mechanisms in the Creation of

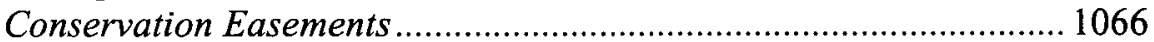

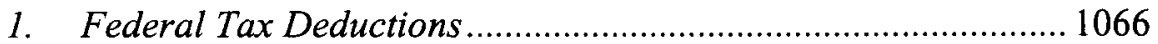

2. Unclogging the Market............................................................. 1070

B. Principle II: Enhance Easement Holder Governance and
Operations............................................................................... 1070

1. Stewardship and Enforcement ................................................1070

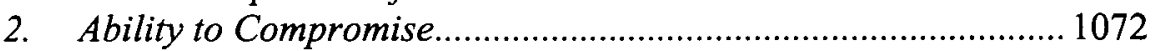

C. Principle III: Protect Expectations of Future Generation Owners..... 1073

D. Principle IV: Achieving Flexibility Through Expanded Modification and Termination Doctrines ............................................................... 1076

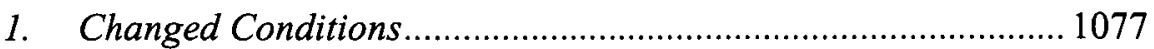

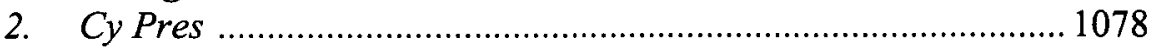

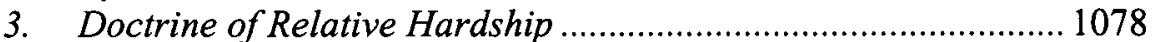

4. Covenants Violating Public Policy ...........................................1080

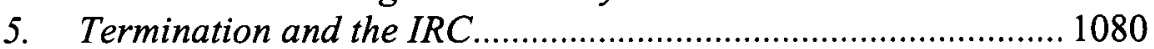

E. Principle V: Preserving the Public's Power of Eminent Domain....... 1081

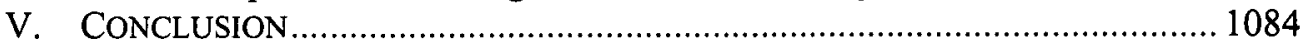




\section{INTRODUCTION}

Book Twelve of Homer's Odyssey' tells how Odysseus avoided the lure of the Sirens' singing from the nearby shore that had enticed many other sailors to shipwreck and death. On the counsel of Circe, Odysseus plugged the ears of his sailors with wax so they could ignore the voices, stay by their oars and propel their ship past the Sirens' promontory. Odysseus ordered his men to tie him tightly to the mast. So bound, Odysseus would be able to hear the beautiful words and voices, but the inflexible restraints would prevent him from leaping to his death. And so the ship proceeded, with his men adding further bonds when Odysseus indicated his desire to break free, until it passed beyond the reach of the Sirens' call. The unyielding ties on Odysseus protected him from his own curiosity, if not folly, in the face of a deadly peril. ${ }^{2}$

Standing alone, the narrative of Odysseus and the Sirens could be read as advocating for the placing of inflexible restraints on people and preventing them from altering course. But the lens should be zoomed out and the story should instead be seen in the context of the entire Odyssey, a life journey both physical and spiritual. ${ }^{3}$ In that broader voyage, Odysseus was not tied to the mast but stood on deck piloting his ship as master of his vessel. ${ }^{4}$ Thus, his binding to the mast should be understood as a unique and extreme measure, necessary because of extraordinary danger. The lashing to the mast is not representative, nor prescriptive, for how Odysseus met the many other demands on his trip. Binding restraints have their role at times, but flexibility opens the way to myriad opportunities and benefits.

This broader, contextual understanding of the narrative of the binding of Odysseus to the mast provides a helpful lesson for the law of property and perpetual real property arrangements. Binding arrangements can certainly be beneficial at times, providing certainty and clarity. But because human needs and desires, technology, and the condition and ecology of land all shift over time, parties to consensual arrangements and the law have usually opted for agreements and doctrines that permit the flexibility necessary to respond to inevitable change. Facing certain danger, Odysseus temporarily bound himself, but on an uncertain

${ }^{1}$ HOMER, THE OdYSSEY 170-83 (Edward McCrorie Trans., Johns Hopkins Univ. Press 2004).

${ }^{2}$ For interpretations of the Sirens story, see Gerald K. Gresseth, The Homeric Sirens, 101 Transactions \& Proc. OF THE AM. Philological Ass'N 203, 203-18 (1970), and Albrecht Wellmer, The Death of the Sirens and the Origin of the Work of Art, 81 NEW GERMAN CRITIQUE 5, 5-19 (2000).

${ }^{3}$ On the meaning of The Odyssey, see R.B. Rutherford, The Philosophy of the Odyssey, 106 J. OF HellenIC STUD. 145, 145-62 (1986), and Michael J. Shapiro, Politicizing Ulysses: Rationalistic, Critical, and Genealogical Commentaries, 17 POL. THEORY 9, 9-32 (1989).

${ }^{4}$ While he did not have free will as we today would understand it, he had freedom of choice to the extent permitted by the fates and ancient gods of the text. 
voyage he needed freedom and flexibility to respond to the endless and unknown obstacles he encountered.

Private conservation easements embody a similar tension between restraints and flexibility. Over the past three decades, nonprofit organizations and trusts have been granted the authority to hold conservation easements. A conservation easement empowers the nonprofit to perpetually prevent the owner of the property subject to the easement from altering the property's scenic and ecological status quo. Such conservation easements are referred to as being "private" or "privately held," in contrast to being owned by a governmental body. ${ }^{5}$ Moreover, the nonprofit may hold the conservation easement "in gross"-meaning that the nonprofit is not required to own neighboring land benefited by the easement, and it can enforce its ownership interest from outside of the community in which the burdened property is located. ${ }^{6}$

Conservation easements held by private nonprofit organizations serve important interests of this generation and those to come by preserving ecologically valuable property. By preventing the often irreversible destruction of natural features, landscapes, habitat, and open space, conservation easements serve a vital public need. The current legal regime and incentive system of conservation easements, however, simultaneously create a serious risk of binding future generations with outmoded and rigid restrictions on land. Inevitable changes in the human condition, society, technology, and ecology may require the shift of land use patterns in the future. Future generations will likely be required to make

${ }^{5}$ See, e.g., Harris v. United States, 19 F.3d 1090, 1092 (5th Cir. 1994) (conservation easements placed on property by federal Farmer's Home Administration); Sabine River Auth. v. United States, 745 F. Supp. 388, 391 (E.D. Tex. 1990), aff'd, 951 F.2d 669 (5th Cir. 1992) (federal Department of the Interior's Fish and Wildlife Service acquisition of conservation easements); Mira Mar Mobile Cmty. v. City of Oceanside, 14 Cal. Rptr. 3d 308, 318-19 (Cal. Ct. App. 2004) (conservation easements used by city as part of environmental impact mitigation of proposed building project); Conservation Law Found., Inc. v. Town of Lincolnville, $2001 \mathrm{ME} 175, \uparrow 10,786$ A.2d 616, 619-20 (town practice of conditioning subdivision plan on developer granting conservation easement was permitted); Dept. of Hous. \& Cmty. Dev. v. Mullen, 886 A.2d 900, 903 (Md. Ct. Spec. App. 2005) (conservation easement on historical property granted to division of state department); Friends of Shawangunks, Inc. v. Knowlton, 476 N.E.2d 988, 989 (N.Y. 1985) (enforcing conservation easements purchased by Palisades Interstate Park Commission in 1977); see also Frederick W. Cubbage \& David H. Newman, Forest Policy Reformed: A United States perspective, 9 FOREST POL'Y \& ECON. 261, 270-71 (2006) (describing ongoing use of conservation easements by federal forest programs); Brian W. Ohm, The Purchase of Scenic Easements and Wisconsin's Great River Road: A Progress Report on Perpetuity, 66 J. AM. PLAN. ASS'N 177, 178 (2000) (reporting on government program that began in the 1960s).

${ }^{6}$ Conservation easements may not be held by private parties or for-profit entities unless they own a neighboring property benefited by the easement. See UNIF. CONSERVATION EASEMENT ACT $§ 1(2)$ \& cmt., 12 U.L.A. 170-79 (1996) (limiting ownership to charitable and governmental entities); id. $\S 4,12$ U.L.A. 179-80 (not requiring the easement to be "appurtenant," or attached to a benefited parcel). 
choices that we cannot now imagine. As to the ones that we can contemplate, such as the tradeoff between conservation and economic development or affordable housing, we cannot and should not determine the balance that future generations should strike in light of their needs and conditions. There is a risk, therefore, of the current generation creating a network of conservation easements that no longer serves environmental purposes and at the same time frustrates future generations from using the land to meet their pressing needs. This danger is exacerbated because control over important public land issues has been delegated to nonrepresentative, nonaccountable private organizations.

These threats can be mitigated, however, and the value of private conservation enhanced, if legislators and courts follow five principles to implement needed reforms. These principles include: first, restoring market mechanisms in the creation of conservation easements; second, enhancing easement holder governance and operations; third, protecting the expectation of future generation owners; fourth, achieving flexibility through expanded modification and termination doctrines; and fifth, preserving the public's power of eminent domain. By taking these steps, we can give future generations the benefits of conservation, but at the same time allow them to find their own better paths when they require flexible solutions.

Part II shows the dramatic growth in private conservation easements over the past thirty years, stemming from the adoption of authorizing legislation that reversed common law impediments. It examines the federal and state tax subsidies that underlie many conservation easements. It also highlights key features of private conservation easements-perpetuity and in gross ownership-that represent a break from prior legal rules and traditional concerns about restrictions on land. Part III examines the advantages and concerns with private conservation easements. It analyzes the value of conservation of natural environment, the benefit of private rather than governmental action, the efficiency of private easement arrangements, and the freedom of choice of property owners. It also identifies and evaluates the disadvantages of conservation easements. First, the cost of tax subsidies is significant and growing, and Congress has not produced meaningful reform legislation. Moreover, there is a lack of public planning and process in private organizations' decisions on conservation easements, which affect local land use. This loss of democratic local land use control is exacerbated by in gross ownership, allowing distant organizations to hold conservation easements and by potential or real class conflicts. Additionally, there are concerns about consistent stewardship of easements and whether nonprofits can and will be flexible in their enforcement when the public interest requires modification and perhaps termination.

Despite these questions about the current structure of conservation easements, Part IV argues for the continuation of private conservation easements. It also, however, proposes important modifications of legal rules in accordance with the five principles described above. First, to enhance market operations, the Internal Revenue Code (IRC) should be amended to permit a deduction only if federal, state, or local government has approved the particular conservation easement. The 
states should also require local recorders to maintain clearer records of conservation easements so that policymakers and market players can better identify and account for them. Second, state attorneys general should play a greater role in the enforcement of conservation easements and ensure that good governance practices are maintained by nonprofits holding such interests. Moreover, state law must be clarified to allow nonprofit boards flexibility to deal with conservation easements without fear of breaching their fiduciary duty. Third, courts should follow doctrines of strict construction when interpreting conservation easements so that future owners of the burdened property are not restricted without fair notice. Fourth, the courts should deny injunctive enforcement of, or even terminate, conservation easements when enforcement would violate public policy. Finally, the legislatures and courts should reaffirm eminent domain power to terminate conservation easements for economic development purposes, in light of the postKelo narrowing of this power by state courts and legislatures.

These steps will preserve the benefits of private conservation easements while minimizing their negative effects on current and future citizens. This will make conservation easements a true gift to those that follow us.

\section{THE ORIGINS AND DEVELOPMENT OF CONSERVATION EASEMENTS}

\section{A. Defining Conservation Easements}

The term "conservation easement" first received notice in the late 1950s, and has grown in recognition over the years. ${ }^{7}$ Conservation easements are negative

${ }^{7}$ William H. Whyte, Jr. popularized if not coined the phrase, and was an early proponent. William H. Whyte, Jr., Securing Open Space for Urban America: Conservation Easements, URBAN LAND INST.: TECHNICAL Bull., Dec. 1959, at 36. Early influential legal writers and supporters of conservation easements included RUSSELL L. BRENNEMAN, PRIVATE APPROACHES TO THE PRESERVATION OF OPEN LAND (Conservation and Research Foundation 1967) and Roger A. Cunningham, Scenic Easements in the Highway Beautification Program, 45 DENV. L.J. 168 (1968). For a history of the land trust movement and its work on conservation easements, see Richard Brewer, CONSERVANCY: The Land Trust Movement IN AmeriCa (Univ. Press of New England 2003). For prior work on conservation easements, see Gerald Korngold, Privately Held Conservation Servitudes: A Policy Analysis in the Context of in Gross Real Covenants and Easements, 63 TEX. L. REV. 433 (1984). Other articles on conservation easements include James Boyd, Kathryn Caballero \& R. David Simpson, The Law and Economics of Habitat Conservation: Lessons from an Analysis of Easement Acquisitions, 19 STAN. ENVTL. L.J. 209 (2000); Federico Cheever, Public Good and Private Magic in the Law of Land Trusts and Conservation Easements: A Happy Present and a Troubled Future, 73 DENV. U. L. REV. 1077 (1996); John L. Hollingshead, Conservation Easements: A Flexible Tool for Land Preservation, 3 ENVTL. LAW. 319 (1997); Jessica Owley Lippmann, The Emergence of Exacted Conservation Easements, 84 NEB. L. REV. 1043 (2006); Nancy A. McLaughlin, Rethinking the Perpetual Nature of Conservation Easements, 29 HARV. ENVTL. L. REV. 421 (2005); Peter M. Morrisette, Conservation Easements and the Public Good: Preserving the Environment on Private Lands, 41 NAT. RESOURCES J. 373 (2001); Melissa 
restrictions that bar the owner of the burdened parcel from altering its ecological, natural, open, or scenic features. ${ }^{8}$

Conservation easements employ provisions designed to preserve the subject property in the current condition, without further development or degradation of natural features. Some conservation easement documents provide an overall statement of purpose to conserve the property's natural and scenic features and then a catchall undertaking by the property owner not to take actions that would violate this purpose. ${ }^{9}$ Easement documents typically include specific clauses, such as those that limit or prohibit additional building on the premises, timber cutting or tree removal, subdivision of the parcel, grants of rights-of-way easements, construction of roads and driveways, storage of trash, the use of all-terrain vehicles, or disturbance of the surface. ${ }^{10}$ The easement may enumerate specific actions related to the particular property that the owner may take consistent with the easement, such as maintaining and replacing a deck and boat house or pruning trees to maintain a scenic view, ${ }^{11}$ building an additional residence,${ }^{12}$ or maintaining and repairing the existing dwelling. ${ }^{13}$ Importantly, conservation easements protecting natural habitat do not usually grant access to the public to the burdened property, ${ }^{14}$ and easements protecting open space only grant "visual (rather than

$\mathrm{K}$. Thompson \& Jessica E. Jay, An Examination of Court Opinions on the Enforcement and Defense of Conservation Easements and Other Conservation and Preservation Tools: Themes and Approaches to Date, 78 DENV. U. L. REV. 373 (2001).

${ }^{8}$ UNIF. CONSERVATION EASEMENT ACT \& 1(1), 12 U.L.A. 170; see also CONN. GEN. STAT. $\$ 47-42 a$ a) (2005). A related interest is a "historic façade easement" that prevents alterations or obstructions in the facades of buildings, or requires preapproval for such actions. See, e.g., Bagley v. Found. for the Pres. of Historic Georgetown, 647 A.2d 1110, 1113-14 (D.C. App. 1994) (upholding summary judgment against property owner who modified his home in violation of easement).

${ }^{9}$ See, e.g., Glass v. Comm'r, 471 F.3d 698, 703 (6th Cir. 2006); see also Rattee v. Comm'r, 761 A.2d 1076, 1078 (N.H. 2000) (barring activities that "result in rendering the site no longer suitable for agricultural use"); Boyd, Caballero \& Simpson, supra note 7, at 222 tbl.1.

${ }^{10}$ See, e.g., Glass, 471 F.3d at 703 (barring subdivision and new buildings); McLennan v. United States, $24 \mathrm{Cl}$. Ct. 102, 104 (1991) (permitting subdivision and construction of four new homes), aff'd, 994 F.2d 839 (Fed. Cir. 1993); Goldmuntz v. Town of Chilmark, 651 N.E.2d 864, 867 (Mass. App. Ct. 1995) (barring billboards, signs, dumping of soil, removal of minerals or soil, activities detrimental to drainage). For a description of various possible restrictions, see ANTHONY ANELLA \& JOHN B. WRIGHT, SaVing the Ranch: Conservation Easement Design IN the American West 61-67 (2004).

${ }^{11}$ See, e.g., Glass, 471 F.3d at 704.

${ }^{12}$ See, e.g., Southbury Land Trust, Inc. v. Andricovich, 757 A.2d 1263, 1264 (Conn. App. Ct. 2000).

${ }_{14}^{13}$ See, e.g., Goldmuntz, 651 N.E.2d at 867.

${ }^{14}$ See 26 C.F.R. $\S 1.170 \mathrm{~A}-14(\mathrm{~d})(3)(\mathrm{iii})$ (2007) (not requiring public access); Brenneman, supra note 7 , at 100 . 
physical) access" to a portion of the property. ${ }^{15}$ Thus, except for conservation easements creating recreational rights, public access is usually not granted. ${ }^{16}$ Conservation easements may, however, allow access for occasional inspections by the easement holder. ${ }^{17}$

\section{B. The Growth in Conservation Easements}

There is limited data on the number and acreage of conservation easements that currently exist. The vast majority of states do not require a special index or set of recording books for conservation easements. ${ }^{18}$ During a title search of a specific parcel the searcher should find a conservation easement properly recorded against it, but there is no centralized list of all conservation easements within the jurisdiction. ${ }^{19}$ Thus, it is difficult to see the full scope, pattern, and number of conservation easements within an area or state. Some reports indicate that even land trusts holding conservation easements were unclear as to the easements that they owned. ${ }^{20}$ Lack of information makes it difficult for policymakers and

1526 C.F.R. $\S 1.170 \mathrm{~A}-14(\mathrm{~d})(4)(\mathrm{ii})(\mathrm{B})$. It is claimed that "[t]he public receives the benefit of keeping land in open space for scenic vistas and in working land uses." The Nature Conservancy, Conservation Easements: Facts vs. Fiction, http://www.nature.org/about us/howwework/conservationmethods/privatelands/conservationeasements/about/myths.html (last visited Dec. 30, 2007).

${ }^{16}$ See ANELLA \& WRIGHT, supra note 10, at 66 ("The overwhelming majority of easements grant no rights to the public to enter the property."); Boyd, Caballero \& Simpson, supra note 7, at 222 tbl.1; ElIZABETH BYERS \& KARIN MARCHETTI PONTE, THE CONSERVATION EASEMENT HANDBOOK 21 (2d ed. 2005) ("A conservation easement requires public access only if the primary conservation value of the property is public recreational or educational use."); see also 26 C.F.R. $\S 1.170 \mathrm{~A}-14$ (d)(2)(ii).

${ }^{17}$ See, e.g., Glass v. Comm'r, 471 F.3d 698, 704 (6th Cir. 2006) (providing the donee land trust with a right to enter the property for monitoring and scientific collection purposes). A provision for entry to inspect is required for a federal tax deduction. See 26 C.F.R. $\S 1.170 \mathrm{~A}-14(\mathrm{~g})(5)(\mathrm{ii})$

${ }^{18}$ A few states have such requirements. See, e.g., United States v. Ponte, 246 F. Supp. $2 \mathrm{~d} 74,75$ (D. Me. 2003) (referring to conservation easement books); CAL. GovT. CODE $\S$ 27255(a) (West Supp. 2007) (mandating county recorders to maintain a comprehensive index of all conservation easements created after 1/1/02); N.Y. ENVTL. CONSERV. LAW $\S$ 49-0305(4) (McKinney 1997) (requiring that the easement must be recorded locally as other real estate documents and copy sent to state department "which shall maintain a file of conservation easements").

19 Massachusetts, with its statutory requirement of state and local governmental approval for all conservation easements, MASS. ANN. LAWS ch. 184, §§ 31-32 (LexisNexis 2007), has been able to compile a list of conservation easements. See JEFF PIDOT,

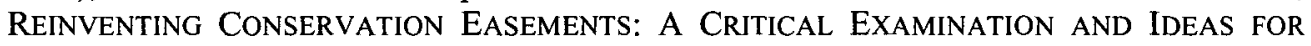
REFORM 12 (Lincoln Institute of Land Policy 2005).

${ }^{20}$ See PIDOT, supra note 19, at 12 (citing report of Bay Area Open Space Council that one-third of surveyed land trusts lacked list of easements); STAFF OF S. FINANCE COMM., 108Th CONG., RePort ON The NAture CONSERvancy, pt. 2, 2 (2005), available at 
potential market players to get a comprehensive view of conservation easements, which essentially establish a land use regulation scheme, within an area.

Still, there are some numbers indicating the significant growth of privately held conservation easements in America. ${ }^{21}$ According to a 2005 Land Trust Alliance report, local and state land trusts in the United States held easements on over 6.2 million acres, showing a $148 \%$ increase from the 2000 figure of 2.5 million. ${ }^{22}$ The Nature Conservancy reported in 2007 that it holds over 3.2 million acres of land under conservation easements, in addition to the land held by local and regional land trusts. ${ }^{23}$ The Land Trust Alliance and The Nature Conservancy combined figures yield over 9 million acres under conservation easements, and this does not include conservation easements held by other types of nonprofit organizations or land trusts not included in the Land Trust Alliance report. ${ }^{24}$ Nine

http://www.senate.gov/ finance/sitepages/TNC\%20Report.htm (follow "Part Two" hyperlink) [hereinafter REPORT ON THE NATURE CONSERVANCY].

Different sources offer widely different totals. For example, the Nature Conservancy reports that in New York there are 685,000 acres under conservation easements held by local and regional land trusts, while the Land Trust Alliance reports only 191,095 acres held by local and state land trusts. Conservation Easements in New York, Mar. 2005, http://www.nature.org/aboutus/howwework/conservationmethods/privatelands/conservation easements/files/ce_newyork.pdf; LAND TRUST ALlianCE, 2005 NATIONAL LAND TRUST CENSUS REPORT 20, chart 5, available at http://www.lta.org/census/2005_report.pdf [hereinafter 2005 CENSUS REPORT].

${ }^{21}$ Conservation easements have also spread to the international arena. See Charles E. Di Leva, The Conservation of Nature and Natural Resources through Legal and MarketBased Instruments, 11 RECIEL 84, 88 (2002); Anastasia Telesetsky, Graun Bilong Mipela Na Mipela No Tromweim: The Viability of International Conservation Easements to Protect Papua New Guinea's Declining Biodiversity, 13 GEO. INT'L ENVTL. L. REV. 735, 737 (2001); Joshua P. Welsh, Comment, Firm Ground for Wetland Protection: Using the Treaty Power to Strengthen Conservation Easements, 36 STETSON L. REV. 207, 239-46 (2006); Press Release, American Bird Conservancy, Spectacular Hummingbird Protected by First Conservation Easement in Northern Peru (July 18, 2006), http://www.abcbirds. org/media/releases/spatuletail_release.htm.

${ }^{22} 2005$ CENSUS REPORT, supra note 20 , at 8 . There are also numerous media reports of specific conservation easements. See, e.g., Shannon McCaffrey, Ga. Rocker Donates Conservation Easement, Mar. 19, 2007, http://www.usatoday.com/life/music/2007-03-191874986560_x.htm (300 acre tract donation by Rolling Stones keyboardist Chuck Leavell); Billingsgazette.com, Rocky Mountain Front Range Under Conservation Easement, Feb. 6, 2007, http://www.billingsgazette.net/articles/2007/02/06/news/state/44-front.txt, (4300 acre ranch conservation easement purchased by the Nature Conservancy).

${ }^{23}$ Conservation Easements in New York, supra note 20 (stating 3.2 million acres held by The Nature Conservancy and 5.1 million acres as of 2003 by local and regional land trusts). For a discussion of the growth of conservation easements in the period of 19881998, see Julie Ann Gustanski, Protecting the Land: Conservation Easements, Voluntary Action, and Private Lands, in PROTECTING THE LAND: CONSERVATION EASEMENTS PAST, PRESENT, AND FutURE 9, 9-25 (Julie Ann Gustanski \& Roderick H. Squires eds. 2000).

${ }^{24}$ See, e.g., News Release, Univ. of Tex. at Austin, Office of Public Affairs, University of Texas at Austin Signs Conservation Easement for Fennessey Ranch (Aug. 11, 
million acres is an area equivalent to the aggregate size of Rhode Island, Delaware, Connecticut, and Hawaii. ${ }^{25}$ Moreover, the data show that conservation easements are becoming the conservation tool of choice. From 2000 to 2005, land trusts increased their fee holdings by only $40 \%$ compared to $148 \%$ for conservation easements. ${ }^{26}$

Common law rules in most jurisdictions either barred privately held conservation easements or placed their legality into serious doubt. ${ }^{27}$ Legislative validation within the states was necessary to reverse common law prohibitions and give donors and organizations confidence to create these interests. The drive for such statutes during the 1970s led to the promulgation of the Uniform Conservation Easement Act in $1981,{ }^{28}$ subsequently adopted by twenty jurisdictions. ${ }^{29}$ The Act's key operative provision equates conservation easements to traditional easements for the purpose of creation, conveyance, recording, assignment, release, modification, and termination. ${ }^{30}$ Common law objections to conservation easements are specifically rejected. ${ }^{31}$ Other states adopted statutes with similar effect to the Uniform Act. ${ }^{32}$ Conservation easements are now recognized as bona fide real property interests. ${ }^{33}$

2006), http://www.utexas.edu/opa/news/2006/08/msill.html (conservation easement held by University of Texas on 3256 acre ranch).

${ }^{25}$ Joan M. Youngman, Taxing and Untaxing Land: Open Space and Conservation Easements, STATE TAX NOTES, Sept. 11, 2006, at 747-62 n.1.

${ }^{26} 2005$ CENSUS REPORT, supra note 20 , at 8.

${ }^{27}$ See United States v. Blackman, 613 S.E.2d 442, 446-48 (Va. 2005) (discussing common law prohibition and statutory changes that permitted creation of both affirmative and negative easements in gross, even prior to passage of Uniform Act); UNIF. CONSERVATION EASEMENT ACT $\S 4 \&$ cmt., prefatory note, 12 U.L.A. 164, 179 (1996) (discussing common law hurdles to conservation easements). See infra Part II.D.2. on the in gross issue.

${ }^{28}$ See Unif. Conservation EASEMEnT ACT, 12 U.L.A. 163.

29 The jurisdictions and the effective dates are: Alabama (1997), Alaska (1989), Arizona (1985), Delaware (1996), District of Columbia (1986), Georgia (1992), Idaho (1988), Indiana (1984), Kansas (1992), Kentucky (1988), Maine (1985), Minnesota (1985), Mississippi (1986), Nevada (1983), New Mexico (1991), Oklahoma (1999), South Carolina (1991), Texas (1983), Virginia (1988), and Wisconsin (1981). See 12 U.L.A. 54 (Supp. 2006).

${ }^{30}$ UNif. CONSERVATION EASEMENT ACT $\S 2(a), 12$ U.L.A. 170, 173-77.

${ }^{31}$ Id. $\$ 4,12$ U.L.A. $179-80$.

${ }^{32}$ See, e.g., CONN. GEN. STAT. $\S \S 47-42$ a to $-42 \mathrm{c}$ (2005); MASS. ANN. LAWS ch. 184, $\S \S 31-33$ (LexisNexis 2007); MONT. CODE ANN. $\S 70-17-102$ (2006); TENN. CODE ANN. $\S$ 66-9-301 (2004).

${ }^{33}$ See Fenster v. Hadi, No. 870090482 S, 1991 WL 257295, at*4 (Conn. Super. Ct. Nov. 26, 1991) (conservation easement is a clog on marketable title.). 


\section{The Tax Subsidy}

The creation of conservation easements held by nonprofit organizations is usually subsidized by the public purse through tax deductions on the federal and state level ${ }^{34}$ Under $\S 170$ (h) of the IRC, a taxpayer can deduct for federal tax purposes the value of a "restriction"35 "exclusively for conservation purposes"36 that is donated to a "qualified" nonprofit organization. ${ }^{37}$ Providing the $\S 170(\mathrm{~h})$ requirements are met, a private conservation easement given to a nonprofit can qualify for the deduction. Importantly, the deduction is only permitted if the conservation restriction is "granted in perpetuity." 38

Moreover, the presence of a conservation easement, created during the life of the decedent or in her will, lowers the value of the subject property for federal estate tax purposes. ${ }^{39}$ The IRC also provides for postmortem donations of conservation easements by the estate ${ }^{40}$ and an additional exclusion from estate tax for certain conservation easements. ${ }^{41}$ These provisions mean additional revenue losses for the Treasury due to conservation easements.

Local and state tax revenues are also reduced by the presence of conservation easements. Assessments for state and local property taxation are made based on the land's market value, ${ }^{42}$ taking into account the restrictions on the title. Thus, where a conservation easement eliminates the potential for development of the property, the assessed value of the property and hence the tax revenues from the parcel are decreased. ${ }^{43}$ The local municipality must then either cut services because of the

${ }^{34}$ The Land Trust Alliance states that "[a]nother major contributing factor to the surge in private land conservation is the availability of state and federal tax incentives." 2005 CENSUS REPORT, supra note 20 , at 8 .

${ }^{35}$ I.R.C. $\S 170(\mathrm{~h})(2)(\mathrm{C})(2006)$.

${ }^{36} \mathrm{Id} . \S 170(\mathrm{~h})(\mathrm{l})(\mathrm{C})$.

${ }^{37}$ Id. $\S 170(\mathrm{~h})(\mathrm{l})(\mathrm{B})$. For a discussion of $\S 170(\mathrm{~h})$, see C. Timothy Lindstrom, Income Tax Aspects of Conservation Easements, 5 WYO. L. REV. 1, 9-10 (2005); Nancy A. McLaughlin, Increasing the Tax Incentives for Conservation Easement Donations-A Responsible Approach, 31 ECOLOGY L. Q. 1 (2004) (providing a critical analysis of the tax incentives designed to encourage conservation easement donations and proposals to increase those incentives); Stephen Small, Real Estate Developers and Conservation Easements, 19 PROB. \& PROP. May/June 2005, at 24 (discussing the use of $\S 170(\mathrm{~h})$ by real estate developers and the consequences of its implementation).

${ }^{38}$ I.R.C. $\S 170(\mathrm{~h})(2)(\mathrm{C})$.

${ }^{39} 26$ C.F.R. $\S 25.2703-1(\mathrm{a})(4)$ (2007).

${ }^{40}$ I.R.C. $\S 2055(\mathrm{f})$.

${ }^{41} I d$. $\$ 2031$ (c) (permitting the exclusion from the estate of an additional forty percent of the land's restricted value, up to $\$ 500,000$ ).

${ }^{42}$ See Bd. of Assessment Appeals v. Colo. Arlberg Club, 762 P.2d 146, 151 (Colo. 1988 ) (including reasonable future use of the property); JOAN YOUNGMAN, LEGAL ISSUES IN Property VAluation AND TAXATION 55-92 (Lincoln Institute of Land Policy 2006).

${ }^{43}$ See Jet Black, LLC v. Rout County Bd. of County. Comm'rs, 165 P.3d 744, 750-51 (Colo. Ct. App. 2006) (referring to special statutory treatment of conservation easement land under agricultural use); Firethorn Inv. v. Lancaster County Bd. of Equalization, 622 
decreased revenue or increase the tax burden on other citizens to make up for the gap. $^{44}$

States also subsidize the donation of conservation easements through deductions on state income taxes. ${ }^{45} \mathrm{An}$ increasing number of states go farther and provide for an income tax credit, rather than a simple deduction. ${ }^{46}$ Colorado, for example, gives an income tax credit of fifty percent of the easement's value up to a maximum of $\$ 375,000 .{ }^{47}$ Moreover, taxpayers unable to use these credits may sell them to others at approximately eighty to eighty-five percent of face value, or if there is a budget surplus, cash in their credits for a refund from the state ${ }^{48}$ These state subsidies provide additional incentives to federal income tax and local property tax benefits.

\section{Perpetuity and In Gross Ownership}

The modern private conservation easement lasts in perpetuity and may be owned by a party who does not own any property adjacent to the land where the

N.W.2d 605, 610-12 (Neb. 2001) (stating that when land's highest and best use was as a golf course, presence of conservation easements did not reduce its value); Gibson $v$. Gleason, 798 N.Y.S.2d 541, 545 (N.Y. 2005) (upholding trial court's order to reduce property tax assessment because of conservation easement barring subdivision and limiting lot to agricultural uses); Ross v. Town of Santa Clara, 698 N.Y.S.2d 90, 92-93 (N.Y. App. Div. 1999) (holding that since land was already restricted against development, conservation easement did not decrease value); McKee v. Dep't of Revenue, No. TC-4620, 2004 WL 2340265, at *3 (Or. T.C. Oct. 14, 2004) (finding significant effect of conservation easement on value when compared to other properties); Luca v. Lincoln County Assessor, Nos. TC-MD 010953F, TC-MD 010931D, TC-MC 020326C, TC-MD 020484D, 2003 WL 21252488, at*8 (Or. T.C. Mar. 19, 2003) (acknowledging drop in development potential); Daniel S. Stockford, Comment, Property Tax Assessment of Conservation Easements, 17 B.C. ENVTL. AFF. L. REV. 823 (1990). For an excellent discussion of the various jurisdictional treatments of conservation easements for state tax purposes, see Youngman, supra note 25.

${ }^{44}$ See Christopher M. Anderson \& Jonathan R. King, Equilibrium Behavior in the Conservation Easement Game, 80 LAND ECON. 355, 358 (2004); Jonathan R. King \& Christopher M. Anderson, Marginal Property Tax Effects of Conservation Easements: A Vermont Case Study, 86 AMER. J. AGRIC. ECON. 919, 919-20 (2004).

${ }^{45}$ This is usually reflected not by a specific state tax code provision but by the state tracking the federal income tax structure and its deductions. See Jeffrey O. Sundberg \& Richard F. Dye, Tax and Property Value Effects of Conservation Easements 7 \& nn.15-16 (Lincoln Inst. of Land Policy, Working Paper No. WP06JS1, 2006), available at http://lincolninst.edu/pubs/PubDetail.aspx?pubid=1128; Vermont Land Trust, Conservation Easement Donations, http://www.vlt.org/Conservation_Easement_Donations.pdf.

${ }^{46}$ See, e.g., N.Y. TAX LAW $\S 210(38)$ (McKinney Supp. 2007); N.C. GEN. STAT. $\S 105-151.12$ (Supp. 2006); VA. CODE ANN. § 58.1-512 (Supp. 2007); see also Janie E. Bowen, Virginia Tax Commissioner Issues Guidelines on Land Preservation Tax Credit, 53 ST. TAX NOTES 17 (2007).

${ }^{47}$ Colo. ReV. StAT. $\$ 39-22-522$ (2006).

${ }^{48}$ Mountains for the Centuries, ECONOMIST, Feb. 3, 2007, at 35. 
easement is located-also known as in gross ownership. These features, however, run counter to traditional legal rules, attitudes, and policy considerations. Despite legislation that has overruled common law misgivings on these attributes, the policy considerations remain and require accommodation.

\section{Perpetuity}

Privately held conservation easements are typically created for an unlimited duration. While theoretically the duration should be a matter of active negotiation, various factors in combination are yielding a pattern of perpetual conservation easements. First, the Uniform Act reflects the dominant legislative scheme of defaulting to perpetuity by providing that "a conservation easement is unlimited in duration unless the instrument creating it otherwise provides. ${ }^{29}$ Moreover, a conservation easement is deductible under the IRC only if it is "granted in perpetuity." ${ }^{\circ 0}$ That provision is a huge motivation for creating interests with an unlimited life. Finally, conservation organizations typically provide for an unlimited duration in their model documents. ${ }^{51}$

\section{In Gross Ownership}

An easement or a covenant is held in gross when its owner does not have neighboring land that is benefited by the interest on the burdened property. ${ }^{52}$ The Uniform Act, like other legislation authorizing private conservation easements, specifically permits nonprofits to hold these interests in gross. ${ }^{53}$ Thus, through the ownership of easements, an out-of-state nonprofit can control local land use decisions, even though it owns no other land in the area. Because easements can be held in gross, nonprofits have no geographical limits to their easement acquisition programs nor physical limitations on areas in which they can be involved.

${ }^{49}$ UNIF. CONSERVATION EASEMENT ACT $§ 2(c), 12$ U.L.A. 173 (1996). North Dakota is an exception, providing for a ninety-nine year duration. N.D. CENT. CODE $§ 47-05-02.1$ (1999).

50 I.R.C. $\S 170(\mathrm{~h})(2)(\mathrm{C})(2006)$. The Tax Act of 1976, which first created conservation easement donation deductions, originally provided for deductibility of an easement with a thirty-year duration, but that was subsequently changed to the perpetual requirement. Youngman, supra note 25, at 749.

51 See ANELLA \& WRIGHT, supra note 10, at 153; The Nature Conservancy, Conservation Easements: Facts vs. Fiction, http://www.nature.org/aboutus/howwework/ conservationmethods/privatelands/conservationeasements/about/myths.html (last visited Dec. 30, 2007); see also United States v. Blackman, 613 S.E.2d 442, 444 (2005) (deed providing "in perpetuity").

52 Gerald Korngold, Private land Use Arrangements: Easements, Real Covenants AND EQuitable SERVITUdes 10-15 (2d ed. 2004). An easement or covenant is appurtenant when the benefit is attached to land owned by the holder near the burdened parcel. Id.

${ }^{53}$ See Unif. Conservation EASEMENT ACt $\$ 4(1), 12$ U.L.A 179. 


\section{Covenants, Easements, and Property Theory}

The presumption of perpetuity and in gross ownership of conservation easements raises serious public policy issues about flexibility and the control of land use policy by nonlocal, private groups. Moreover, allowing unlimited duration and in gross ownership runs counter to both legal theory and doctrinal rules that were traditionally in place, and that had to be supplanted by legislation, to validate private conservation easements.

\section{(a) Conservation Easements, Covenants, or Servitudes?}

Conservation easements are really not "easements" in the way that law has understood such interests. Terming them "easements" is a misnomer. Traditionally, easements were affirmative interests, giving the easement holder the right to do something on the land of another, such as to cross another's land by a right-ofway. ${ }^{54}$ Except for a few rare and limited exceptions, the term "easement" was not applied to negative interests that served to restrict the burdened property owner. ${ }^{55}$ Rather, negative interests were typically created as "covenants" and enforced as "covenants running with the land at law" or "equitable servitudes." 56

Since conservation "easements" typically involve only negative restrictions on the burdened owner's use of her property, they should more accurately be called conservation "covenants." of Property (Servitudes), which unifies easements and covenants for many purposes under the rubric "servitude," these interests could be called conservation "servitudes." 58 Despite the inaccuracy, this Article uses the term "conservation easement" as this has received common acceptance in the legal and popular literature.

\section{(b) Policy Against Restrictions}

This is not merely a matter of semantics. Covenants, unlike easements, have historically been viewed by the courts with suspicion, as reflected in their theoretical musings and rules of law. Courts have often expressed an antipathy towards covenants that create restrictions or restraints on land and state that they

${ }^{54}$ See KORNGOLD, supra note 52, at 1-4.

${ }^{55}$ See id. at 7-10. Common law recognized only a few negative easements-light, air, view, support, and stream flow. The Third Restatement of Property has abolished the category of negative easement. Id.

${ }_{56} \mathrm{Id}$. at 287-93.

${ }^{57} \mathrm{See}$ Found. for the Pres. of Historic Georgetown v. Arnold, 651 A.2d 794, 797 (D.C. App. 1994) (specifically rejecting application of rules of affirmative easements to a façade easement, finding it more akin to a restrictive covenant); Southbury Land Trust, Inc. v. Andricovich, 757 A.2d 1263, 1265 (2000) (applying law of restrictive covenants to a conservation easement).

${ }^{58}$ See Korngold, supra note 7. 
favor a policy of free and unrestricted use of land. ${ }^{59}$ This "antirestrictions policy" has led the courts to declare a hard line against covenants, noting that they are "not favorites of the law." ${ }^{60}$ This antipathy led the law to erect various barriers to the enforcement of covenants, reflected in various common law rules. Two such rules would have made it difficult if not impossible to create private conservation easements at common law. First, some courts attempted to narrow the duration ${ }^{61}$ and operation of covenants ${ }^{62}$ with constructional devices, raising (perhaps surmountable) questions about the perpetual nature of conservation easements. Second, the common law prohibition of enforcement of covenants in gross ${ }^{63}$ would have been fatal to the modern private conservation easement.

Although the courts do not typically explain the reasons for their concern about restrictions created by covenants, the antirestrictions policy serves two important, longstanding goals that resonate in the current conservation easement discussion. First, stripping away restrictions that would hamper the functioning of real estate markets helps to promote efficient use of our limited supply of land. The rule against in gross ownership can be understood in this context. ${ }^{64}$ When a covenant is held in gross, the covenant owner does not need to own a neighboring fee interest to which the covenant attaches and so the covenant owner may be far removed from the area. ${ }^{65}$ And as time passes, there may be multiple owners of the in gross right through inheritance or sale, all living in parts unknown. This may make it expensive or impossible for the fee owner to locate the covenant holder to enter into negotiations about the covenant and to achieve modification or termination. Transaction costs will be high. Moreover, there is no ongoing neighborly exchange between the parties, which is often a lubricant in a give-andtake bargaining process. Without the opportunity to negotiate, the market process cannot work. The prohibition on in gross covenants can be understood as preventing such market malfunction.

Second, the antirestrictions policy expresses a concern about permitting past generations to control current property owners, where the old ties would frustrate the personal autonomy of current owners. ${ }^{66}$ For example, covenants barring occupancy by members of racial and religious groups were denied enforcement

${ }^{59}$ See KORNGOLD, supra note 52, at 358-62.

${ }^{60}$ See, e.g., Genovese Drug Stores, Inc. v. Conn. Packing Co., 732 F.2d 286, 289 (2d Cir. 1984); Frander \& Frander, Inc. v. Griffen, 457 So. 2d 375, 377 (Ala. 1984); Andrews v. Lake Serene Prop. Owners Ass'n, 434 So. 2d 1328, 1331-32 (Miss. 1983).

${ }^{61}$ KORNGOLD, supra note 52, at 381-84.

${ }^{62}$ See id. at 358-62.

${ }^{63}$ See id. at 381-88.

${ }^{64}$ See Gerald Korngold, Resolving the Intergenerational Conflicts of Real Property Law: Preserving Free Markets and Personal Autonomy for Future Generations, 56 AM. U. L. REV. 1525, 1549-51 (2007).

${ }^{65}$ See KoRNGOLD, supra note 52, at 304, 378-79.

${ }^{66}$ For example, direct restraints on alienation can force people to live where they no longer want to remain and prevent them from moving to new areas. RESTATEMENT (THIRD) OF PROP. (SERVITUDES) § 3.4, cmt. c (1998). See Korngold, supra note 64, at 1553-55. 
only in $1948,{ }^{67}$ and covenants are still employed to control the nature of family units living in a residential subdivision. ${ }^{68}$ When courts express general concerns about duration of covenants, they may be reflecting some discomfort with perpetually imposing the past's vision on the lives of the future. Even the frustrating and rough Rule Against Perpetuities teaches the salutary lesson that at some point the past must relinquish power and warns of the dangers of "dead hand" control. ${ }^{69}$ Moreover, the prohibition on in gross ownership of covenants may also reveal that while there is a willingness to tolerate ties between neighbors, a higher level of suspicion attaches when outsiders try to assert control over a distant area.

The choice of the term conservation "easement" by their proponents, despite the inaccuracy under then existing and current legal conceptualizations, may have served the goal of making these interests more accepted by legislators, courts, and parties. In general, easements have long been accepted by the courts while covenants have been viewed with some suspicion. ${ }^{70}$ More specifically, there is no doubt that easements can be created in fee, that is, perpetually, as well as in "in gross." ${ }^{71}$ Semantic sleight-of-hand and legislation removed constraints of the common law rules on conservation easements, but the policy issues remain.

\section{The Policy MatriX: The AdVANTages and ConCerns With Private CONSERVATION EASEMENTS}

\section{A. Advantages of Conservation Easements}

Privately held conservation easements bring significant advantages to current and future citizens. These include conservation of our natural environment, private action, efficiency, and freedom of choice. In combination, these benefits make a powerful case for the continuation of private conservation easements, on both policy and normative levels.

\section{The Conservation Value}

The conceptualization and legislative authorization of private conservation easements reflects a fundamentally new outlook of Americans toward our nation's

${ }^{67}$ See KORNGOLD, supra note 52, at 399.

${ }^{68}$ Gerald Korngold, Single Family Use Covenants: For Achieving a Balance Between Traditional Family Life and Individual Autonomy, 22 U.C. DAVIS L. REV. 951, 951 (1989).

${ }^{69}$ The rule is being repealed by many jurisdictions, for taxation and commercial reasons, without adequate consideration of the social policy. See Robert H. Sitkoff \& Max M. Schanzenbach, Jurisdictional Competition for Trust Funds: An Empirical Analysis of Perpetuities and Taxes, 115 YALE L.J. 356, 430-33 (2005).

${ }^{70}$ See KORNGOLD, supra note 52 , at 2-3.

${ }^{71}$ See id. at 10-15, 28-29. 
land. ${ }^{72}$ From the time of the first European settlers in North America, land had been viewed exclusively as a commercial asset, to be fully exploited by its owner. ${ }^{73}$ In contrast, over the past several decades, Americans have viewed conservation of our natural and historical heritage as an important value to be balanced against a traditional full-development model..$^{74}$ Conservation easements are an important tool to preserve ecological conditions and to protect this new conservation value.

Moreover, development activities on unique environments are highly expensive if not impossible to reverse. ${ }^{75}$ This increases the stakes for effective, strong preservation. For conservation proponents, the fixed, perpetual nature of conservation easements is major plus. ${ }^{76}$

\section{Private Action}

Conservation easements are private, not governmental, initiatives. Given the excessive demands on government for top priority services and the limits of government resources and energy, there are advantages when private citizens step forward to take on roles to improve their communities. Costs of acquisition, monitoring, stewardship, and enforcement of conservation easements are shifted from local, state, and federal government to nonprofit organizations when the holder is a nonprofit rather than a governmental entity. ${ }^{77}$ Furthermore, government actors exercising decision making over conservation easements may be subject to short term pressures and special interests, based on looming elections or the need to derive additional tax revenues through development. ${ }^{78}$ These forces may not make for the best long-term conservation easement policy and practice. In contrast,

${ }^{72}$ See Cary Coglianese, Social Movements, Law, and Society: The Institutionalization of the Environmental Movement, 150 U. PA. L. REV. 85, 91-94 (2001).

${ }^{73}$ See Lawrence M. Friedman, A History of American Law 169 (3d ed. Touchstone 2005); Morton J. Horwitz, The Transformation of american LaW 1780-1860, at 31 (Harvard Univ. Press 1977); Korngold, supra note 64, at 1533-35.

${ }^{74}$ See BREWER, supra note 7, at 8-12; D.T. Kuzmiak, The American Environmental Movement, 157 GEOGRAPHICAL J. 265, 265 (1991); Bob Pepperman Taylor, Environmental Ethics and Political Theory, 23 Polity 567, 577-78 (1991); Adam W. Rome, William Whyte, Open Space, and Environmental Activism, 88 GeOGRAPHICAL Rev. 259, 261-62, 271 (1998).

${ }^{75}$ See Alexander James, Kevin J. Gaston \& Andrew Balmford, Can We Afford to Conserve Biodiversity?, 51 BIOSCIENCE 43, 50-51 (2001).

${ }^{76}$ See ANELLA \& WRIGHT, supra note 10, at 31 (asserting that most land trusts only accept perpetual easements). Certainly the IRC contemplates perpetuity. See supra Part II.C.

77 See BYERS \& PONTE, supra note 16, at 9-10; Dominic P. Parker, Land Trusts and the Choice to Conserve Land with Full Ownership or Conservation Easements, 44 NAT. RESOURCES J. 483, 503-04 (2004); Korngold, supra note 7, at 442-47.

${ }^{78}$ See generally James M. Buchanan, Constraints on Political Action, in PuBLIC FinANCE AND PubliC ChOICE (James M. Buchanan \& Richard A. Musgrave eds. 1999) (discussing public choice theory and pressures on elected government officials). 
nonprofits can hold these easements free of special-interest and short-term pressures.

\section{Efficiency Benefits}

Permitting private conservation easements in gross also yields the market efficiency advantages embodied in the notion of "freedom of contract." The law generally allows a landowner to enter into market transactions with respect to her property and to sell partial interests, such as a lease or a mortgage, in her land. The law upholds these arrangements because free-market exchanges of land achieve an efficient allocation of our limited (and nonrenewable) land resources. ${ }^{79}$

Private conservation easements are a good example of the efficiency benefits of market transactions in fractional interests of real property. The fee owner retains the rights that he wishes in the property (perhaps the right to live in a home or to farm the land) and the nonprofit organization gets the control that they seek (the ability to prevent further development). If the law barred the exchange of this partial interest of the fee, the only way that the nonprofit could prevent development would be to buy the property in fee simple absolute. This would be a poor result as the nonprofit would have to pay a much higher amount, creating an overinvestment in conservation. Also, the landowner would lose the option of cashing out some of the land's value through sale or donation (with tax benefits) of the easement while still living on the land, causing an overinvestment in living space ${ }^{80}$ This is not an efficient use of land resources.

\section{Freedom of Choice}

The notion that people are free to dispose of their property in the marketplace is a key assumption of freedom of contract. Ownership of property entitles the holder to seek her personal happiness and satisfaction by exercising her free choice with respect to the property, whatever that choice may be and whatever other people may think of the wisdom of that decision. The law should trump this freedom of choice of property and impose on this right of property owners only in rare circumstances and for overriding reasons. ${ }^{81}$ Thus, if an owner wishes to donate or sell a conservation easement to a nonprofit organization, she should be able to do so.

79 See Richard A. POSNER, ECONOMIC ANALYSIS OF LAW 9-10 (6th ed. 2003).

${ }^{80}$ See Korngold, supra note 64, at 1543-45.

${ }^{81}$ See Loeb v. Watkins, 240 A.2d 513, 516 (Pa. 1968) ("Where a man's land is concerned, he may impose ... any restrictions he pleases."); JAMES W. ELY, JR., THE GUARDIAN OF EVERY OTHER RIGHT: A CONSTITUTIONAL HISTORY OF PROPERTY RIGHTS 17 (2d ed. Oxford Univ. Press 1998); Richard Epstein, Notice and Freedom of Contract in the Law of Servitudes, 55 S. CAL. L. REV. 1353, 1359 (1982); see also ANELLA \& WRIGHT, supra note 10 , at 16 ("Conservation easements fully respect private property rights. In fact, the tool is a powerful way of helping landowners do what they want with their land."). 


\section{B. Concerns About Conservation Easements}

Although there are compelling policy and normative reasons for permitting private conservation easements, these interests come with costs that must be addressed. Some problems can appear when the easement is created, and others may emerge over time.

\section{Creation}

Permitting private organizations to hold conservation easements raises several concerns at the time of the creation of the interests. These include the tax subsidy to donors; the lack of standards, public participation, and process in the creation of conservation easements; and class issues.

\section{(a) Tax Subsidy}

Very often conservation easements held by nonprofits are in reality not purely private endeavors but rather are subsidized by the public purse through federal or state tax deductions. ${ }^{82}$ It is therefore legitimate for the public to ask whether it is getting full value in exchange for these subsidies.

In the 2003 tax year, federal income tax deductions for conservation and historic easements totaled $\$ 1.49$ billion. ${ }^{83}$ Assuming high bracket taxpayers, the revenue loss to the Treasury could be roughly approximated in the $\$ 600$ million plus range. The presence of a tax benefit does not deny the charitable, environmental motive of the donor ${ }^{84}$ nor the fact that despite the deduction the net

${ }^{82}$ See discussion supra Part I.C. Tax benefits are described by at least some nonprofits on their websites and are otherwise described in the literature. See, e.g., The Nature Conservancy, Conservation Easements-All About Conservation Easements, http://www.nature.org/aboutus/howwework/conservationmethods/privatelands/conservation easements/about/allabout.html (last visited Dec. 30, 2007); see also Christopher E. Williams \& Meredith E. Lathbury, Economic Incentives for Habitat Conservation on Private Land: Applications to the Inland Pacific Northwest, 24 WILDLIFE SOC'Y BULL. 187, 187-88 (1996) (discussing estate tax deferments); Rachel Emma Silverman, Tax Break with a View: Landowners Rush to Take Advantage of New Law That Boosts Deductions for Blocking Development, WALL ST. J., Feb. 7, 2007, at D1 (noting that increased tax breaks have translated into more easements).

${ }^{83}$ Janette Wilson \& Michael Strudler, Individual Noncash Charitable Contributions, 2003, SOI BULL., Spring 2006, at 58, 60, available at http://www.irs.gov/pub/irssoi/03inccart.pdf.

${ }^{84}$ See BYERS \& PONTE, supra note 16 , at 15, 17; Lorna Thackeray, Conservation Easement Preserves Family's Way of Life, BILlings GAZETTE, Feb. 26, 2006, available at http://www.billingsgazette.net/articles/2006/02/26/news/state/25-easement.txt (citing continuity of family ranching as fundamental motivation for the subject of the article). But see John B. Wright, Conservation Easements: An Analysis of Donated Development Rights, 59 J. AMER. PlanNing Ass'N 487, 488-89 (1993) (noting that tax savings is the most common motivation for the donation). 
value of the property to the donor is reduced. In some cases the easement is purchased by the nonprofit, albeit sometimes at a bargain price. ${ }^{85}$ It is clear, though, that where a deduction is taken, the public purse subsidizes the transfer. Abuses, especially through dubious appraisals and insider deals, have also cost the Treasury. ${ }^{86}$ Private conservation easements thus decrease federal revenues.

Moreover, conservation easements have an impact on state and local property tax revenues. The unilateral decision of one homeowner to place a conservation easement on her property can reduce state and local property tax revenues, forcing government to cut services or to increase taxes on other citizens to maintain services. ${ }^{87}$ This could have a negative impact on the municipality's civic agenda and on other residents. ${ }^{88}$ Experimental economics has shown that a donor's decision to create conservation easements is based on her personal welfare maximization and not on a consideration of the effects on others. ${ }^{89}$ Thus, conservation easements pose a cost to local governments and citizens.

State income tax conservation easement programs also create challenges. The annual revenue loss to Colorado from its income tax credit program in 2005 was

${ }^{85}$ See Murphy v. Long, 170 S.W.3d 621, 625 (Tex. App. 2005) (regarding sale of lots by the Nature Conservancy subject to conservation easement, with restriction presumably reflected in the price); BYERS \& PONTE, supra note 16, at 50, 250-251, 270-271 (describing acquisition techniques); Rocky Mountain Front Range Under Conservation Easement, BILlINGS GAZETTE, Feb. 6, 2007, available at http://www.billingsgazette.net/ articles/2007/02/06/news/state/44-front.txt (describing conservation easement purchased by the Nature Conservancy on 4300 acre ranch).

${ }^{86}$ See Youngman, supra note 25, at 749-51. Abuses led to a congressional investigation of the Nature Conservancy and legislation in 2006 to tighten appraisal standards and penalties. See StAfF OF S. COMM. ON FinANCE, 109TH CONG., REPORT ON THE NATURE CONSERVANCY (2005), available at http://www.senate.gov/ finance/ sitepages/TNC\%20Report.htm; see also Pension Protection Act of 2006, Pub. L. No. 109$280, \S 1219,120$ Stat. 1083, 1083-1086 (to be codified at 29 U.S.C. $§ 1219$ ) ("Provisions relating to substantial and gross overstatements of valuations."); STAFF OF J. COMM. ON TAX., 109TH CONG., TEChNICAL EXPlanation OF H.R. 4, at 308-12 (2006). The Nature Conservancy increased its oversight rules as a result. THE NATURE CONSERVANCY, FinAL REPORT OF THE CONSERVATION EASEMENT WORKING GROUP 2 (2004), available at http:// www.nature.org/aboutus/howwework/conservationmethods/privatelands/conservationease ments/files/easements_report.pdf.

${ }^{87}$ See discussion supra Part I.C.

${ }^{88}$ Theoretically, a desirable and effective conservation easement on the donor's property could enhance the value of neighboring properties, increasing the welfare of those owners and the value of their properties. Tax revenues would thus not drop since the increased assessments on the neighboring properties would yield increased revenues when the tax rate is applied. But the effect on neighboring parcels' values is in actuality hard to predict. Youngman, supra note 25, at 753; see also Jacqueline Geoghegan et al., Capitalization of Open Spaces into Housing Values and the Residential Property Tax Revenue Impacts of Agricultural Easement Programs, 32 AGRIC. \& RES. ECON. REV. 33, 34 (2003).

${ }^{89}$ See Anderson \& King, supra note 44, at 357, 360. 
$\$ 85.1$ million, up from $\$ 2.3$ million in $2001 .^{90}$ The cost and conservation efficacy of this program has led to attempts to amend it. ${ }^{91}$ Colorado's program may indeed be consistent with the strong environmental preference of its citizenry and may support its substantial outdoor recreation industry. It is unclear, however, whether the public is getting the maximum benefit for its tax subsidy dollars from a patchwork of private conservation easements that were created without an overall environmental planning process.

\section{(b) Standards, Public Planning, and Process}

Private groups have virtually unlimited discretion in purchasing or accepting donations of easements and do not have to follow standards or a plan in making such determinations. ${ }^{92}$ The nonprofit may simply accept any easement that comes its way, even though the land to be conserved and the terms of the easement are of dubious environmental benefit. Best practices on easement selection and terms may help to address these issues, but they are not a true solution in any case since they would not be mandatory. ${ }^{93}$

Moreover, private organizations do not accumulate conservation easements pursuant to a public land use plan. This can easily result in a patchwork of easements that do not add up to an effective community-wide preservation plan. ${ }^{94}$ Thus, open space and habitat protection can be sited based on the chance decisions of private landowners and unaccountable private groups, appropriately pursuing their own interests and mission but not necessarily the wider and inclusive land use policies that the public desires. Random creation of conservation land is not consistent with modern notions of planning that supports broader, regional, even cross-border approaches to land use planning. ${ }^{95}$ Private decision makers are not

${ }^{90}$ See K.C. Mason, Lawmakers Want To Tighten Controls on Credit for Donated Land, 44 ST. TAX NOTES 146, 146 (2007) (discussing Colorado HB 1361).

${ }^{91}$ Id.

92 Section 1(1) of the Uniform Act merely defines the values inherent in a conservation easement but does not provide a standard or measurement. UNIF. CONSERVATION EASEMENT ACT $\S 1$ 1(1), 12 U.L.A 170 (1996). Section 170(h) of the IRC does provide some limitations for deductibility, but they set a floor, not an optimal level. I.R.C. $\$ 170(\mathrm{~h})$ (2006). See supra Parts II.C. \& III.B.1.a.

${ }_{93}$ See, e.g., ANELLA \& WRIGHT, supra note 10, at 52-81 (summarizing importance of professional design principles); BYERS \& PONTE, supra note 16, at 26-42; Wright, supra note 84 , at 491 (highlighting that conservation easements are not regulatory).

${ }^{94}$ See Heidi J. Albers \& Amy W. Ando, Could State-Level Variation in the Number of Land Trusts Make Economic Sense?, 79 LAND ECON. 31 1, 312 (2003) ("[L]ocal land trusts specializing in providing open space often do not consider the impact of their decisions on regional conservation benefits. ... [L]ack of coordination among [land trusts] has become a serious problem.").

${ }^{95}$ See ANTHONY DOWNS, New Visions For METROPOLITAN AMERICA 26-30, 132-34 (1994); Robert Fishman, The Death and Life of American Regional Planning, in REFLECTIONS ON REgIONALISM 107, 107-123 (Bruce Katz ed., 2000); see also Terri Mashour et al., A Hedonic Analysis of the Effect of Natural Attributes and Deeds 
subject to the accountability of the electoral and regulatory processes that bind governmental officials and decisions.

Even those nonprofits that might follow suggested best practices as to easement selection operate as private entities. They are not subject to the democratic, administrative, and legal constraints of a public land use planning process. Permitting the outsourcing of local land use decisions from a public, governmental procedure to a private entity raises serious concerns that will only multiply as acreage under private conservation continues to increase. ${ }^{96}$ The situation is exacerbated by in gross ownership, where an out-of-state, geographically distant nonprofit that is removed from local issues and citizens, controls patterns of land usage and development. ${ }^{97}$ Indeed, it could corrode public trust in the government if public officials abdicate difficult decisions to the private sector.

Outsourcing public land issues to private organizations through the conservation easement vehicle may also serve the interests of some elected officials. Just as legislators sometimes delegate difficult and potentially unpopular issues to agencies in order to avoid political fallout, ${ }^{98}$ they may be taking similar steps in outsourcing land use decisions-a volatile area of particularly high interest to voters ${ }^{99}$ - to nonprofits. The public deserves better from its elected officials.

\section{(c) Class Issues}

As a related matter, there is the potential for class conflict and elitism in conservation easement creation and enforcement. The effect, if not the intent, of a pattern of conservation easements in a community can be "private large-lot zoning." ${ }^{, 100}$ Limiting development on a large tract to a single (often existing) home can prevent the building of affordable housing in the area or environmentally

Restrictions on the Value of Conservation Easements, 7 FOREST POL'Y \& ECON, 771, 771 (2005) (describing the need for a state-planned program to deal with wildland-urban interface issues).

${ }^{96}$ See supra Part II.B.

${ }^{97}$ See supra Part II.D.1.

${ }^{98}$ See DAVID SCHOENBrod, Power Without Responsibility: How CONGRESS Abuses the PEOPle Through Delegation 82 (1993).

${ }^{99}$ See William A. Fischel, The Homevoter Hypothesis: How Home Values Influence Local Government Taxation, School Finance, and Land-Use Policies $1-3(2005)$.

${ }^{100}$ Consider, for example, the recent dispute between environmentalists seeking to preserve scenery and those supporting the development of lower income housing for immigrant laborers living in crowded conditions in Monterey, California. See Miriam Jordan, In Tony Monterey County, Slums and a Land War, WALL ST. J., Aug. 26-27, 2006, at Al. 
friendly unit developments. A pattern of conservation easements may actually increase the exclusivity of the neighborhood and keep out newcomers. ${ }^{101}$

Despite his promotion of conservation easements, William $\mathrm{H}$. Whyte noted the inherent "muted class and economic conflicts" in this endeavor. ${ }^{102} \mathrm{He}$ believed that the donors of conservation easements would be the "gentry" and that their interest was in natural areas in the countryside rather than open space for parks and playgrounds. Thus, there is a divergence of interests on conservation questions and without a public process to manage the friction, there is a risk that traditionally powerful groups will be successful in privately imposing their vision. An unrepresentative, parochial, homogenous, self-perpetuating nonprofit board of directors of an organization that holds a conservation easement could exacerbate potential negative class perceptions and effects. ${ }^{103}$ People may associate with whomever they wish, and they should be free to pursue their own happiness and interests, but that does not mean that public land-policy should be delegated to such private groups.

\section{(d) Governmental Easements}

The growth of private conservation easements should not mask the public's positive attitudes towards governmentally owned conservation easements. Moreover, data indicate that the public is willing to pay for the acquisition of such easements. Seventy-seven of 1630 ballot measures providing funds for land conservation between 1994 and 2005 were approved, providing $\$ 31.1$ billion in funding. ${ }^{104}$ Other reports show that citizens are willing to pay for governmental acquisition of conservation easements. ${ }^{105}$ While far from perfect, government has

101 See Burlington County NAACP v. Twp. of Mt. Laurel, 336 A.2d 713, 724-25 (N.J. 1975) (declaring the obligation of towns to provide fair share of affordable housing within the state).

${ }^{102}$ Whyte, supra note 7, at 37.

103 See Alice Korngold, Leveraging GoOd Will: Strengthening NONPROFITS BY ENGAGING BUSINESSES 138-142 (2005) ("The right board composition and structure in the past is unlikely to be the right composition and structure today and tomorrow."); David Lipton, Significant Private Foundations and the Need for Public Selection of Their Trustees, 64 VA. L. REV. 779, 781 (1978); see also John B. Wrights, Cultural Geography and Land Trusts in Colorado and Utah, 83 GEOGRAPHICAL REV. 269, 277-278 (1993) (finding factors in disparity in numbers and success of land trusts between areas: cultural values, economic conditions, transient population, racial composition, and political attitudes). The Land Trust Alliance's Standards and Practices, Standard 3B (2004) calls for a board with "diverse skills, backgrounds and experiences." Land Trust Alliance, http://www.lta.org/sp/land_trust_standards_and_practices.pdf (last visited Dec. 30, 2007). The key to increasing diversity of perspective and background will be in adoption, interpretation, and implementation of this and similar standards.

${ }^{104}$ See Andrew J. Plantinga, The Economics of Conservation Easements, in LAND Policies AND TheIR OUtCOMES 91-92 (Lincoln Institute of Land Policy 2007).

${ }^{105}$ See, e.g., Seong-Hoon Cho, David H. Newman \& J.M. Bowker, Measuring Rural Homeowners' Willingness to Pay for Land Conservation Easements, 7 FOREST POL'Y \& 
been able to successfully plan and execute major infrastructure and public projects over the generations. The citizenry could expect and require them to effectively manage a conservation easement program.

\section{Ongoing Nature}

In addition to concerns at the time of creation, conservation easements present challenges over the years of their existence. These include stewardship and the perpetuity issue.

\section{(a) Stewardship}

While many organizations do a fine job of stewarding the conservation easements that they hold, others do not fare as well. ${ }^{106}$ Quality stewardship requires periodic inspection and monitoring of the burdened property, discussions with the fee landowner over general issues and incipient and actual violations, and enforcement actions if resolution of disputes becomes impossible. ${ }^{107}$ Without adequate stewardship, the conservation benefit to be enjoyed by the public dissipates. Where a tax benefit accompanied the creation of the easement, this means that the public has paid for a conservation advantage that has been squandered through inaction or misjudgments of a nongovernmental organization. The risk of stewardship failure is greatest, but not exclusive, to poorly funded, inadequately governed nonprofits that lack the institutional and financial capital to develop and maintain quality stewardship programs. The stewardship gap and loss of publicly financed easements clearly has public policy ramifications.

There has been a concerted effort by leading conservation groups to provide education and best practices for stewardship, as well as a recommendation that nonprofits seek accompanying stewardship funds from donors of conservation easements. ${ }^{108}$ This advice may help the situation-longitudinal studies will

ECON. 757, 768 (2005); Brad Haire, Georgians Want to Preserve Farmland, SOUTHEAST FARM PRESS, May 19, 2004, http://southeastfarmpress.com/mag/farming_goergians_ preserve_farmland/index.html (reporting on a University of Georgia survey); California Growers Permanently Protect Land, AMERICAN NuRSERYMAN, Mar. 1, 2002 (reporting on a California program of easement acquisition and bond issues).

106 See Pidot, supra note 19, at 18-19; see also REPORT ON THE NATURE CONSERVANCY, supra note 20 , pt. 2, at 2-4 (criticizing monitoring efforts); $i d$. exec. summary, at 10 (suggesting loss of tax-exempt status and imposition of officer and director excise taxes for failure to monitor and enforce).

107 See ANELLA \& WRIGHT, supra note 10, at 137-143; BYERS \& PONTE, supra note 16 , at $143-168$.

108 See ANELla \& Wright, supra note 10 , at 28; Byers \& Ponte, supra note 16, at 126. For example, The Land Trust Alliance and Trust for New Hampshire Lands with assistance from the National Trust for Historic Preservation published BRENDA LiND, THE Conservation EAsement Stewardship Guide: Designing, Monitoring and ENFORCING EASEMENTS (1991). 
ultimately tell the story. But more importantly, these steps are not mandatory on nonprofits and there is no evidence that they will be adopted and implemented effectively, especially by those low-performing nonprofits who most need to upgrade their operations.

\section{(b) Perpetuity and Flexibility}

Perhaps the greatest risk of conservation easements comes from what many view as their most important attribute - their perpetual nature. ${ }^{109}$ While advocates of conservation easements seek to prevent changes in the land forever, it is unclear whether this serves the public welfare in all situations. First, our sense of what is ecologically and scenically valuable and the best methods to preserve such areas evolve over time. Establishing immutable conservation easements may ultimately frustrate conservation efforts in the future. ${ }^{110}$

Moreover, history shows us that the constant shifts in the human condition, technology, and economic arrangements have meant differing uses of land over the generations. There may come a point in the future where a parcel of land subject to a conservation easement is best suited for development as a commercial or industrial property to provide employment in a economically depressed area, or for affordable housing for moderate income residents in an area where little developable land remains and large private homes dominate, or for some other socially desirable purpose.

Typically decisions about developing undeveloped land are made in two arenas: the market place and the public land use process. In the first, the parties negotiate and reach agreement on the economic terms of a land transfer and development deal. The deal is subject to being shaped in the second arena--the zoning, subdivision, environmental regulation, and related land use control processes-that gives the public a voice in the nature of the project. This two-track development process functions today, albeit with high transaction costs and many complaints, and is how socially desirable and economically feasible projects get completed.

If, however, the land is subject to an existing conservation easement, this twotrack process may be unable to function. First, the presence of a conservation easement held by a nonprofit creates a flawed market process, almost by definition. Conservation organizations, appropriately devoted to their mission of land conservation and opposed to land development, rarely enter market exchanges to sell (that is release) their conservation rights. Conservation organizations may be unwilling, regardless of the price, to sell their easement rights for various reasons:

${ }^{109}$ Marketable title acts may provide no relief, even in those states that have adopted such legislation. See Restatement (Third) of Prop. (SERvitudes) § 7.16(5) (1998) (exempting conservation easements from marketable title acts).

${ }_{110}$ See Julia D. Mahoney, Perpetual Restrictions on Land and the Problem of the Future, 88 VA. L. REV. 739, 783-84 (2002). 
creation of complications for the donor under the IRC, ${ }^{111}$ concerns about their own nonprofit tax status, ${ }^{112}$ doubts about the power to make such sales under their governing documents, and misgivings that potential donors will no longer trust them to hold conservation easements which will prevent them from accomplishing their mission. ${ }^{113}$

The market process may be further impeded. A low-functioning, merged, or defunct nonprofit will likely not be a viable negotiating partner for an owner seeking to purchase the release of a conservation easement. ${ }^{114}$ Moreover, since conservation easements can now be held in gross, there may be a problem in finding the easement owner because the owner is no longer tied to the neighborhood, and could literally be located anywhere in the world. Thus, markets may simply not be an answer to deal with removal of conservation easements.

Furthermore, the public does not get its usual input into the decision as to whether the conservation easement will be relaxed to accommodate the public interest in light of current conditions. Rather, the nonprofit owner will decide on its own and in a nonpublic process whether to enforce its easement or yield to the asserted public interest for flexibility. ${ }^{115}$ Thus, this key decision on local land use control will be made outside of the public view and electoral process and without public participation. The nonprofit may be based at a geographical distance from the locality, without key facts and understanding of the issues. Notions of local, democratic control over key land use decisions would be violated. ${ }^{116}$ Issues of class and elitism may influence decisions as well, perhaps not out of ill will but because

${ }^{111}$ See 26 C.F.R. $\S 1.170$ A-14(c)(2) (2007) (placing limits on transfer by easement donees, but allowing termination for changed conditions if proceeds are used for new conservation purpose); Lisa Black \& Courtney Flynn, Couple Sue Neighbor Over Use of Conservation Land, CHI. TRIB., Dec. 1, 2005, Metro, at 1 (describing concerns of nonprofit by allowing modification of easement).

${ }_{112}$ See Brad Wolverton, Conservation Charities Come under Questioning by the Senate, The Chronicle of Philanthropy, June 23, 2005, at 4 (describing the intense scrutiny facing these organizations). REPORT ON THE NATURE CONSERVANCY, supra note 20 , exec. summary, at 10-12 (suggesting that the Senate consider revoking tax-exempt status and imposing excise taxes on officers and directors for failure to monitor).

${ }^{113}$ In the event of a transfer or release of a conservation easement, the consideration should be reinvested for conservation purposes and should be commensurate with any original deduction taken by the easement donor, or else there would be a revenue loss to the public by allowing a deduction and receiving no public benefit. See infra Part IV.D.5.

114 The organization may no longer be filing annual IRS Form 990s, making it hard to locate.

${ }^{115}$ Contrast this with the significant public process in the enforcement of governmental conservation easements. See, e.g., Friends of Shawangunks, Inc. v. Clark, 754 F.2d 446, 452 (2d Cir. 1985).

${ }^{116}$ See Chattowah Open Land Trust, Inc. v Jones, 636 S.E.2d 523, 526-27 (Ga. 2006) (removing land trust as holder of conservation easement as it is not approved to do business in the state and substituted the county as holder; and dismissing objections that county may have conflict in the future if it seeks to widen nearby road). 
the conservation easement owner lacks the opportunity to hear different viewpoints on the issue. ${ }^{117}$

Finally, perpetual conservation easements that lock in future generations, no matter how well meaning, can violate the autonomy of future citizens. Land ownership has played an important economic, social, and political role in America, from the time of the first European settlers to the current day. ${ }^{118}$ Land is also a limited resource, and by its nature nonrenewable. While future citizens no doubt will, and should, be grateful to the current generation for many actions that conserve the environment for the future, the price cannot be the loss of the ability of coming generations to make important decisions on land use for themselves based on then-current needs, values, and tradeoffs. ${ }^{119}$ The current generation must allow adequate flexibility in conservation easements and cannot have the hubris to think that the answer of today will be the answer of eternity. Thus, in order to meet intergenerational responsibilities, a balance must, and can, be struck between the conservation values of the current generation and the autonomy of future generations.

\section{FIVE PRINCIPLES FOR IMPROVING THE LAW OF CONSERVATION EASEMENTS}

As demonstrated in Part III, there are significant concerns about the devolution of key land use control decisions to private citizens and organizations. Effective public policy decision making in the land use arena requires accountability of actors. ${ }^{120}$ That typically includes voter control of key decisions and/or officials-a situation not present when independent nonprofits are making policy. Transparency is also a precondition to accountability. ${ }^{121}$ This requires

${ }^{117}$ Consider the inherent class issues in the recent dispute in Marin County, California over an attempt by Habitat for Humanity to build four affordable housing units in the face of criticism that this would increase traffic and be inconsistent with the neighborhood. Jim Staats, Crowd Rips Habitat for Humanity Proposal, MARIN INDEPENDENT J., Jan. 17, 2007, available at $\mathrm{www}$.marinij.com/marin/ci_5029025.

${ }^{118}$ See Korngold, supra note 64, at 1532-38.

${ }^{119}$ This would violate the value of free alienability of land. See supra Part II.D.3.b.

${ }^{120}$ See Ehtisham Ahmad, Maria Albino-War \& Raju Singh, Subnational Public Fiscal Management: Institutions and Macroeconomic Considerations, in HANDBOOK OF FISCAL FEDERALISM 408 (Ehtisham Ahmad \& Giorgio Brosio eds. 2006) (discussing that fixed terms of office, fair elections, independent judiciary, and auditors are essentials for democracy); Rebecca L. Brown, Accountability, Liberty, and the Constitution, 98 Colum. L. REV. 531, 539-41 (1998) (describing prevailing view of accountability); Eric Maskin \& Jean Tirole, The Politician and the Judge: Accountability in Government, 94 AMER. ECON. REV. 1034, 1037 (2004) (describing literature on elections and accountability); Jerome B. McKinney, Process Accountability and the Creative Use of Intergovernmental Resources, 41 PUB. ADMIN. REV. 144 (1981) (evaluating costs and performance).

121 See Lindsay Stirton \& Martin Lodge, Transparency Mechanisms: Building Publicness into Public Services, 28 J.L. SOC'Y 471, 477-79 (2001) (suggesting four transparency mechanisms: information, choice, representation, and voice); Dennis E. 
standardized information flows-hardly present under the current system where even data on the number, location, and acreage of existing conservation easements cannot be readily ascertained. Transparency also requires a strong probability of the detection of abuse and effective political and legal processes to resolve them; given other demands on attorney-general and regulatory resources, it is unclear how much detection and investigation of abuses is realistically possible under current conditions. ${ }^{122}$ Equity is another major concern of public poilicy decision making; so, it is fair to ask whether private conservation organizations can effectively meet the needs of an economically, socially, and racially diverse America. Potential problems with stewardship and inflexibility present serious challenges for future generations.

Yet, the reasons for validating and using private conservation easements remain powerful: the growing conservation value, the benefits of private initiative, efficiency gains, and freedom of choice for property owners. Conservation easements are attractive to many landowners and citizens. Therefore, private conservation easements in gross should continue to be authorized by the legislatures and the courts, provided some changes are made to address the most pressing issues. The following part describes five principles that, if adopted by legislatures and courts, will strengthen the legal structure of conservation easements for current and future generations.

\section{A. Principle I: Restore Market Mechanisms in the Creation of Conservation Easements}

One of the claimed benefits of private conservation easements is that they represent private rather than nongovernmental activities, based on consensual rather than compelled transactions. Two aspects of conservation easements, however, need to be reformed to address market distortions resulting from the creation of conservation easements under the current legal regime: the federal tax subsidy and the system for recording conservation easements.

\section{Federal Tax Deductions}

The current version of the IRC allows tax benefits for conservation easement donations that might not bring matching public benefits. Deductions in those cases create incentives that encourage transactions that yield an inefficient market allocation of our limited land resources. The tax incentive system also frustrates organized and public land use planning.

Thompson, Democratic Secrecy, 114 PoL. SCl. Q. 181, 182, 184-86 (1999) (describing need for information).

122 See Susan N. Gary, Regulating the Management of Charities: Trust Law, Corporate Law, and Tax Law, 21 U. HAw. L. REV. 593, 622-24 \& nn.245-52 (1999) (describing limited actions by attorneys general, limited resources, and methods of operation). 
Under $\S 170(\mathrm{~h})$, a donation of a conservation easement qualifies for a deduction if it is for a "conservation purpose." Such a purpose includes "the preservation of land areas for outdoor recreation by or education of the general public"; "the protection of a relatively natural habitat of fish, wildlife, or plants, or similar ecosystem"; or the preservation of open space for "the scenic enjoyment of the general public or pursuant to a clearly delineated" governmental conservation policy, and that "will yield a significant public benefit." 123 Qualifying for the open space deduction thus requires either "scenic enjoyment" (the regulations provide eight factors to determine this, using vague terminology since aesthetic considerations are being described) ${ }^{124}$ or consistency with a local, state, or federal governmental policy (with the regulations requiring a focused and specific government policy). ${ }^{125}$ Then, with either open space easement scenario, the easement must meet the "significant public benefit" test, with the regulations describing eleven, again elastic, factors to consider in this determination. ${ }^{126}$ Only a few cases on natural habitat and open space easements have been reported, ${ }^{127}$ and they do not provide much guidance to taxpayers or the IRS.

Beyond the administrative concerns engendered by such ambiguity, there is the public subsidy question. Property rights and freedom-of-contract notions support the removal of common law restraints on property owners' ability to create conservation easements benefiting nonprofits. But this should not be conflated with the separate question of whether the public should subsidize the free choice of owners through a tax deduction. This is especially so when the benefits of the conservation easement are somewhat amorphous and unverifiable, in particular when compared to other conservation investments that the public could make. Neither the natural habitat nor the open space conservation easement categories require physical access to the public in order to qualify for deductibility. ${ }^{128}$ With open space easements, the public must only have a view of part of the property, but the extent of what they must be allowed to see and the benefit they receive are unclear. ${ }^{129}$ It is fair to ask what the public is getting in return for its investment, especially since the choice of the property is being made by private parties outside of a public land use plan or process.

${ }^{123}$ I.R.C. $\$ 170(\mathrm{~h})(4)(\mathrm{A})(\mathrm{i})$ to (iii) (2006).

${ }^{124} 26$ C.F.R. $\$ 1.170$ A-14(d)(4)(i) to (ii) (2007)

${ }^{125} 26$ C.F.R. $\S 1.170 \mathrm{~A}-14(\mathrm{~d})(4)(\mathrm{i})$, (iii). Historic easements are a fourth category of conservation easement. I.R.C. $\S 170(\mathrm{~h})(4)$ (A)(iv) (2007).

${ }^{126} 26$ C.F.R. $\S 1.170$ A-14(d)(4)(iv).

${ }^{127}$ See, e.g., Glass $\because$ Comm'r, 471 F.3d 698, 708 (6th Cir. 2006) (affirming finding that habitat areas were "significant" over challenge of IRS); Turner v. Comm'r, 126 T.C. 299, 313-14 (2006) (finding open space requirement not met since easement did not restrict building on buildable lots and there could be no building on the remaining acreage as it was in a floodplain).

${ }^{128} 26$ C.F.R. $\S 1.170$ A-14(d)(3)(iii), (4)(ii)(B).

${ }^{129} \mathrm{Id}$. 
Moreover, tax subsidies for conservation easements motivate owner choices in the marketplace. ${ }^{130}$ Legislators must ensure that public benefits actually result and that the subsidy does not distort market behavior and cause a suboptimal allocation of our limited land resources. The worst-case scenario would be a patchwork of conservation easements that has been purchased with mostly public dollars, but that provides dubious public value, is not part of an overall conservation plan, is controlled by a private entity, remains perpetually with the property, and frustrates the legitimate land use, conservation, and development goals of citizens for the land in their area. This is not a description of current reality but the challenge is how to maintain the benefits of private conservation easements and avoid these potential problems.

In contrast to the natural habitat and open space categories, an easement for the preservation of a historically important land area or historic structure will qualify for a deduction only if there is governmental process and action. ${ }^{131}$ Claimed historic land must be listed in the National Register and a building must be listed either in the National Register or be a part of a registered historic district and certified by the Secretary of the Interior as being of historic significance. ${ }^{132}$ The National Register process involves standards, administrative action, and public participation that includes state historic preservation officers, a state review board (comprised of professionals, property owners, and local officials), a federal advisory council, and the National Park Service as decision maker. ${ }^{133}$ The Secretary of the Interior also sets out specific requirements for administrative certification of historic districts. ${ }^{134}$ The presence of a governmental decision maker, process, and articulated standards make it more likely that the public will receive a benefit in exchange for the tax subsidy.

Therefore, the IRC should be amended to require local, state, or federal governmental certification that the conservation easement serves a public conservation purpose in order for its donor to receive a federal tax deduction. This certification would be required only in the case of open space and natural habitat conservation easements that do not include a meaningful right of physical access by the public. ${ }^{135}$ To be valid, the certification decision would have to be consistent with a specific local, state, or federal conservation plan, and the governmental agency must approve the particular easement on the specific parcel in question. Although the federal deduction does not cost local and state treasuries, one would expect them to be judicious in considering applications since the creation of an easement will likely mean a reduction in state and local property tax revenues ${ }^{136}$

${ }^{130}$ See Wilson \& Strudler, supra note 83.

${ }^{131}$ I.R.C. $\$ \S 170(\mathrm{~h})(4)(\mathrm{A})(\mathrm{iv}),(\mathrm{h})(4)(\mathrm{C})(2007)$.

${ }^{132}$ I.R.C. $\$ 170(\mathrm{~h})(4)(\mathrm{C})$.

${ }^{133}$ See National Register Criteria for Evaluation, 36 C.F.R. $§ 60.4$ (2007), available at http://www.nps.gov/history/nr/listing.htm.

${ }^{134}$ See 26 U.S.C. $\$ 47$ (c)(3)(B) (2007); 36 C.F.R. $\$ 67.4$.

${ }^{135}$ Easements for education or recreation that grant public access should not require governmental approval--the public access is a clear and tangible benefit.

${ }^{136}$ See supra Parts II.C. \& III.B.1.a. 
and since it will affect local land policy. In any case, preapproval is not currently required for federal deductions, so it is hard to imagine how the tax expenditure will increase under the proposed system.

The benefits of such a system are clear-improving the planning process for conservation easement creation, ensuring that public funds are well spent, and avoiding market distortions. ${ }^{137}$ There are costs, but they are justified: transaction costs will increase, as donors and nonprofits must go through a governmental approval process, and it may slow down the process. ${ }^{138}$ Bureaucracy may grow. The complication or ultimate denial of a deduction may also dissuade some owners from creating conservation easements. ${ }^{139}$ However, Massachusetts, which presently requires governmental approval to create any conservation easement even if a deduction is not sought, has been able to create a high number of conservation easements even with that requirement in place. ${ }^{140}$ Currently $0.9 \%$ of Massachusetts land is controlled by conservation easements held by state and local land trusts. This is a high number in comparison to other states that do not have such an approval requirement, for example, New York (0.4\%), Arizona (0.04\%), and Iowa $(0.01 \%){ }^{141}$

The proposal here does not affect the validity of private conservation easements in gross, just their potential deductibility under federal tax law. It is different than the current Massachusetts legislative scheme that allows the creation of a conservation restriction only if there is local and state governmental approval. ${ }^{142}$ The Massachusetts legislation, while perhaps a good choice for that state and its resources and culture, can be viewed in other places as unnecessarily stifling the free choice of property owners to achieve their personal conservation wishes. The proposal suggested above, however, simply provides that there is no automatic right to a public subsidy for a conservation easement without public access. The owner may still give freely without subsidy, or receive a deduction

${ }^{137}$ The Senate Report for the 1980 legislation states that "the committee believes that provisions allowing deductions for conservation easements should be directed at the preservation of unique or otherwise significant land areas or structures." S. REP. NO. 961007 , at 9 (1980), reprinted in 1980 U.S.C.C.A.N. 6736, 6745 (emphasis added).

${ }^{138}$ If delays become a problem, the Code might provide a presumed approval after a set period of time after an application.

${ }^{139}$ Another alternative that would address concerns about validity of the deduction under current standards but not the issue of governmental planning would be pre-approval of deductions by the IRS. See generally REPORT ON THE NATURE CONSERVANCY, supra note 20 , exec. summary, at 11 .

${ }_{140}$ MASS. ANN. LAWS ch. 184, \& 31-32 (LexisNexis 2007).

${ }^{141}$ These percentages are compiled from 2005 CENSUS REPORT, supra note 20, at 20 chart 5, and U.S. Census Bureau, State and Metropolitan Area Data Book: 2006, tbl. E-1, http://www.census.gov/compendia/smadb/TableE-01.pdf (last visited Dec. 30, 2007) (the factor of 640 acres per square mile was used to convert area figures).

${ }^{142}$ The drafters of the Uniform Act specifically rejected governmental approval to create a conservation easement. UNIF. CONSERVATION EASEMENT ACT prefatory note, 12 U.L.A. 165 (1996). 
without the necessity of governmental approval by donating a fee or an easement with meaningful public access. ${ }^{143}$

Despite the intensive congressional investigation and study of conservation easements and abuses, ${ }^{144}$ the 2006 tax reform legislation made only few and insubstantial changes in the deductibility of conservation easements. ${ }^{145} \mathrm{~A}$ more serious response, as suggested here, is needed.

\section{Unclogging the Market}

Information is a prerequisite for effective functioning of policymakers and markets. Currently, the recording system does not provide good data about the ownership of conservation easements. ${ }^{146}$ We lack good figures on key conservation easement questions: the number of easements, the amount of acreage, current holders of interests (that is, assignees), and the nature of the restrictions. Developing this data would enhance the public discourse about the costs and benefits of conservation easements, enable better decision making by legislatures and officials, and more clearly identify restrictions to potential market players. Therefore, all jurisdictions should require separate recording books for conservation easements within the county recorder offices.

Enhanced data available from a recording book requirement will also serve the antirestrictions policy. This information will enable policymakers to easily recognize the full range of restrictions, allowing them to take the necessary actions taken to limit the dead hand. ${ }^{147}$ Additionally, transaction costs generated by perpetual, in gross interests can be reduced, ${ }^{148}$ preventing the frustration of the efficient operation of the land transactions system. Costs to establish such a book system for conservation easements on a going-forward basis should be minimal and are worth the investment.

\section{B. Principle II: Enhance Easement Holder Governance and Operations}

\section{Stewardship and Enforcement}

The many responsible, effective nonprofits holding conservation easements have been unfairly tarnished by the improper acts of a few. Concerns about nonprofit holders of conservation easements tend to focus on a lack of capability to

${ }^{143}$ Other aspects of IRC $\S 170$ that have received recent attention have been proposals to prevent appraisal abuses, see supra note 86 , and proposals to accredit conservation organizations, see REPORT ON THE NATURE CONSERVANCY, supra note 20, exec. summary, at 11 .

144 See REPORT ON THE NATURE CONSERVANCY, supra note 20.

145 Pension Protection Act of 2006, Pub. L. No. 109-280, $\S 1219,120$ Stat. 1083, 1083-1086 (to be codified at 29 U.S.C. $\S 1219$ ) (placing penalties on abusive appraisals).

146 See supra Part II.B.

${ }^{147}$ See supra Part II.D.3.b.

${ }^{148}$ See supra Part II.D.2. 
effectively manage, monitor, and enforce the easements and frivolous waiver of easement provisions-with the result that the benefit of the easements and the public subsidy can be lost. ${ }^{149}$

Various attempts have been made to address these issues. In order for a donor's deduction to be valid, the IRC requires that a donee organization must have the resources to enforce the restriction, ${ }^{150}$ and the easement must provide for a right of access to the property by the organization to monitor compliance. ${ }^{151}$ Still, there is nothing to guarantee that the organization will be effective, especially over the long term.

Congressional staff has also raised the possibility of accreditation of easement holders in order to address stewardship and enforcement problems, ${ }^{152}$ although such a provision did not appear in the 2006 reform legislation. The Land Trust Alliance has developed a voluntary program of accreditation for land trusts and detailed standards and practices, and is currently rolling out the accreditation process through a lottery system, as demand is high. ${ }^{153}$ This program may increase operational quality of those organizations that receive certification. Still, participation in the program is only voluntary, and the poorer performing organizations are likely to avoid the costs and transparency that accreditation will bring. Moreover, it is unclear that the fact that an organization has received accreditation will affect the actions of a donor who is primarily motivated by the tax deduction. As long as the federal income tax bar is cleared, best practices may not be of interest. ${ }^{154}$

The solution may come through the power of attorneys general in the various states to intervene, as the representatives of the public, in matters related to charitable gifts and nonprofit organizations and trusts. ${ }^{155}$ An attorney general could enforce a conservation easement when a nonprofit fails to do so or take a position on enforcement contrary to the nonprofit on modification of the easement where the public interest requires. Additionally, the attorney general could pursue breach of fiduciary duty actions against nonprofit board members where appropriate. The possibility of action against board members can be an effective and necessary motivator of board behavior.

${ }^{149}$ See supra Part III.B.2.a.

${ }_{150} 26$ C.F.R. $\$ 1.170 \mathrm{~A}-14$ (c)(1) (2007).

15126 C.F.R. $\S 1.170$ A-14(g)(6)(ii).

152 REPORT ON THE NATURE CONSERVANCY, supra note 20, exec. summary, at 11 . This raises many questions, such as who would administer such a program? at what cost? with what demonstrable benefits?

${ }^{153}$ See Land Trust Accreditation Commission, http://www.landtrustaccreditation.org (last visited Dec. 30, 2007) (an independent program of the Land Trust Alliance); Maggie I. Jaruzel, Land Trusts Seek Self-Regulation Through Accreditation, MOTT MOSAIC, Apr. 2006 , at 12,12 , available at http://www.mott.org/upload/pdfs/current/mott\%20mosaic/ mosaicv5n1.pdf.

${ }^{154}$ See supra note 84.

${ }^{155}$ See Evelyn Brody, The Limits of Charity Fiduciary Law, 57 MD. L. REV. 1400, 1463 (1998); Gary, supra note 122, at 593. 
There are some difficulties with achieving attorney general intervention. First, customs in the various states have meant different levels of intervention by attorneys general over the years. ${ }^{156}$ Second, there is the cost to the attorneys general of enforcement, especially given other, arguably more serious, demands on the budget. Since stewardship and enforcement of conservation easements have been an ongoing concern and a major public issue, it might be possible to attach a special fee to the creation of these interests to go to an attorney general monitoring and enforcement fund.

Third, some jurisdictional issues would have to be resolved. Consider the example of a Virginia nonprofit that holds a conservation easement on Montana land, and the nonprofit fails to monitor and enforce. The attorney general of Virginia may not be interested or well informed about the land dispute in Montana, but would be concerned about governance issues of the nonprofit. The attorney general of Montana, on the other hand, might be interested in the land but not in ongoing governance issues of the nonprofit. The interests of both states would need to be accommodated and protected.

Finally, there is again the issue of whether the attorney general even knows of the existence and terms of a given conservation easement within the jurisdiction. To address this, the recorder of deeds should be required to notify the attorney general of conservation easements that are presented for recording. ${ }^{157}$

\section{Ability to Compromise}

Nonprofit operations and culture create another set of issues. As discussed above, ${ }^{158}$ sometimes it may be necessary in the public interest for a nonprofit to amend or release a covenant. Nonprofit directors may fear to do so, out of a concern over IRS regulations governing easement holders ${ }^{159}$ or language in the

${ }^{156}$ See Evelyn Brody, Whose Public? Parochialism and Paternalism in State Charity Law Enforcement, 79 IND. L.J. 937, 950-53 (2004).

157 There has been some suggestion that third parties, as opposed to the attorney general, should be empowered to enforce private conservation easements. See Carol Necole Brown, A Time to Preserve: A Call for Formal Private-Party Rights in Perpetual Conservation Easements, 40 GA. L. REV. 85, 126 (2005); Jessica E. Jay, Third-Party Enforcement of Conservation Easements, 29 VT. L. REV. 757, 759 (2005). This, however, would lead to increased litigation and associated costs. Moreover, this would mean the further privatization of a public land issue, as the public's interest would be represented not by a public official but by a private citizen perhaps having different perspectives and goals. The cases are unclear on the third party standing issue. See, e.g., Spirit of Sage Council v. City of Pasadena, No. BC267782, 2006 WL 3199929, at *15 (Cal. Ct. App. Nov. 7, 2006) (rejecting third party standing); Burgess v. Breakell, No. CV-95-0068033, 1995 Conn. Super. LEXIS 2290, at *3 (Conn. Super. Ct. Aug. 7, 1995); Tenn. Envtl. Council, Inc. v. Bright Par 3 Assocs., L.P., No. E2003-01982-COA-R3-CV, 2004 WL 419720, at *3 (Tenn. Ct. App. Mar. 8, 2004) (finding standing for all citizens within the state). Interestingly, all three cases are not released for reporting and are thus subject to citation limitation rules.

${ }^{158}$ See supra Part III.B.2.b.

${ }^{159} 26$ C.F.R. $\S 1.170 \mathrm{~A}-1(\mathrm{c})(2),(\mathrm{g})(6)(2007)$. 
easement document or organizational documents. Statements such as the one from Senator Charles Grassley, then chair of the Senate Finance Committee, that "modifying these easements is a huge no-no"160 can intimidate nonprofit directors from making appropriate decisions in the public interest.

Obtaining declaratory judgments that board actions are permitted is a cumbersome, expensive, and impractical process. Directors insurance and lawyers' opinion letters may give some comfort. Better methods must be developed, though, to empower directors to act in those rare instances when the public interest requires deviation from the terms of a conservation easement. Judicial or legislative development of an expanded concept of fiduciary duty, that would encompass flexibility and not conservatism, may be a good first step.

\section{Principle III: Protect Expectations of Future Generation Owners}

A number of reported cases interpret the disputed meaning of language in conservation easements. In developing rules of interpretation of conservation easements, the courts should remember that these are perpetual interests that will be enforced against successor owners to the servient parcel. They must protect the interests of future generation owners living with these restrictions.

"General" contracts (as opposed to real property agreements) usually are enforced between the original parties to the transaction. In such cases, there is some divergence of judicial approach on interpretation of the agreement. Some courts prefer to look to the language of the document exclusively if at all possible, believing that this best reflects the parties' intent-a "strict construction," "plain language," or "objective" approach. ${ }^{161}$ Others, however, place greater weight on extrinsic evidence, reflecting an attitude that particular words can be imprecise or can have special meanings to the original parties-a "subjective" approach. ${ }^{162}$

Regardless of the particular view controlling "general" contracts, interpretation of conservation easements should follow a strict-construction approach. Over time there will be successor owners of the burdened parcel ${ }^{163}$ and in some cases the easement right may be transferred to another organization. ${ }^{164}$

${ }^{160}$ Black \& Flynn, supra note 111 , at 1.

${ }^{161}$ See Beanstalk Group, Inc. v. AM Gen. Corp., 283 F.3d 856, 859-60 (7th Cir. 2002).

${ }_{162}$ See Restatement (SECOND) OF CONTRACTS $\$ 212, \mathrm{cmt}$. b (1981).

${ }^{163}$ See, e.g., Southbury Land Trust, Inc. v. Andricovich, 757 A.2d 1263, 1266 (Conn. App. Ct. 2000); Sagalyn v. Found. for the Pres. of Historic Georgetown, 691 A.2d 107, 109 (D.C. App. 1997); Redwood Constr. Corp. v. Doornbosch, 670 N.Y.S.2d 560, 561-62 (N.Y. App. Div. 1998); see also Dept. of Hous. \& Cmty. Dev. v. Mullen, 886 A.2d 900, 903 (Md. Ct. Spec. App. 2005) (occupant of property subject to conservation easement controlled by its terms).

${ }_{164}$ See, e.g., United States v. Blackman, 613 S.E.2d 442, $445-49$ (Va. 2005) (validating an easement transferred to the National Park Service); see also UNIF. CONSERVATION EASEMENT ACT $\S 2(\mathrm{a}), 12$ U.L.A. 173 (permitting assignment of easement 
Successors will likely have no knowledge of extrinsic evidence not appearing in the language of the recorded document, and should not be bound by information of which they are unaware. Instead, the courts should, whenever possible, interpret conservation easement language involving successors by relying exclusively on the express language of the document. In rare cases the courts may have to allow extrinsic evidence when the language does not produce a meaning. The courts in these situations, though, should not allow evidence that was unknown to the successor. ${ }^{165}$

Moreover, the court should not be aiming to establish the original meaning of the language to the initial parties. Rather, it should look at the point in time that the successor purchased and determine what a reasonable successor should have thought that the original agreement meant, based on the language of the recorded instrument and, if necessary, extrinsic evidence known to the successor. This will protect the legitimate expectations of successors of the burdened parcel. It also places the burden on the easement owner (who may continue to own the easement perpetually) to make the terms of the easement clear and to spell out any special understandings on the face of the original document for successor servient purchasers to see before committing.

Unfortunately, various courts apply "general" contract interpretation principles to conservation easement cases too glibly, without recognizing the successor issue involved in recorded conservation easements. They refer to the contest as a matter of contract ambiguity, interpretation, and extrinsic evidence. Even when a successor is involved, they still adhere to the bilateral, general contract language. ${ }^{166}$

Fortunately, despite these troubling articulations, some cases have strictly applied the language of conservation easements and rejected attempts to broadly read the words or bring in other understandings to alter the "clear" terms of the agreement. Sometimes this close reading protects the servient owner from a conservation easement owner's attempt to restrain activities. ${ }^{167}$ For example, in one case, a nonprofit conservation organization sought to bar the building of an additional house on the burdened property for the easement grantor's son. ${ }^{168}$ The

benefit); BYERS \& PONTE, supra note 16, 169-173 (describing use of back-up holders of easements).

${ }^{165}$ See Sagalyn, 651 A.2d at 797 (rejecting appraisal report as providing meaning in enforcement against second generation owner as it was prepared only by the grantor and was for tax purposes).

${ }^{166}$ See, e.g., Southbury Land Trust, Inc., 757 A.2d at 1265 (relying on language in the document and zoning regulations to interpret "where the language of the contract is clear and unambiguous" (citing Tallmadge Bros. v. Iroquois Gas Transmission Sys., 746 A.2d 1277, 1288 (Conn. 2000))); Redwood Constr. Corp., 670 N.Y.S.2d at 561 (involving successor owner of burdened parcel, but court stated "where, as here, a contract is unambiguous on its face," as a result no external evidence was needed) (emphasis added).

${ }_{167}$ See, e.g., Sagalyn, 651 A.2d at 798 (refusing to construe "extension" to bar addition of dog run and canopy).

${ }^{168}$ Southbury Land Trust, Inc., 757 A.2d at 1266. 
court found that the "plain language" allowing the construction of "an additional dwelling unit" for a family member did not require it to be situated in an already existing building but could be new, free-standing construction. ${ }^{169}$ Sounding antirestrictions strains, the courts stated that "a restrictive covenant must be narrowly construed and ought not to be extended by implication."170 This strict reading appropriately balances the competing interests by protecting the legitimate expectations of the servient owner and not creating land ties where none were intended. If the conservation group had wanted to bar new construction, "they easily could have accomplished this by adding certain language to the restriction." 171

In other cases, a narrow reading of the language serves the conservation purpose. For example, in a case involving a conservation easement granted by a predecessor to the local government, the court ruled that a current life tenant could not build a pool as it was a "structure on or above the ground" and barred by the language. ${ }^{172} \mathrm{~A}$ pool would also conflict with the grantor's purpose stated in the easement document to "restrict the use of [the property] and retain it predominantly in its natural, scenic and open condition.",173

Perhaps the strongest example of strict enforcement of a conservation easement's terms against a successor involved the purchase of a property subject to an existing restriction limiting the use of the property to farming, wildlife sanctuary, or nature conservation area. ${ }^{174}$ The purchasers obtained a building permit for a 4900 -square-foot house and the defendants brought an action to prevent construction. During the pendency of the suit, the purchasers built their residence. The court ultimately found for the defendants, and ordered the purchasers to vacate their home and to remove it. The court granted the defendants the right to enter and remove the house if the purchasers failed to do so. The defendants contracted with a demolition company to remove the house and the company demolished the residence. This strict application of the conservation

${ }^{169} I d$. at $1265-66$.

${ }^{170}$ Id. at 1265 (quoting 5011 Cmty. Org. v. Harris, 548 A.2d 9, 11 (Conn. App. Ct. 1988)); accord Sagalyn, 651 A.2d at 798.

${ }_{171}$ Southbury Land Trust, Inc., 757 A.2d at 1266; see also Conrad v. Mattis, No. CV0005959545, 2000 WL 33115395, at*3 (Conn. Super. Ct. Dec. 20, 2000) (noting that there were "some differences of opinion as to the exact definition of "clear-cutting" but finding, based on the dictionary, governmental regulations, and academic definitions that it did not include the cutting of some trees to put in a vegetable garden where use as a farm or garden was specifically permitted by the easement).

${ }^{172}$ Goldmuntz v. Town of Chilmark, 651 N.E.2d 864, 865-66 (Mass. App. Ct. 1995); see also United States v. Ponte, 246 F. Supp. 2d 74, 78-79 (D. Me. 2003) (finding that distance should be measured horizontally, according to the prevailing custom, and so holding that the easement has been violated).

${ }^{173}$ Goldmuntz, 651 N.E. 2d at 865; see also Bagley v. Found. for the Pres. of Historic Georgetown, 647 A.2d 1110, 1113 (D.C. App. 1994) (finding that building that obscured façade violated specific language of easement).

${ }^{174}$ Natale v. Schwartz, 151 F. Supp. 2d 562 (E.D. Pa. 2001). 
easement is noteworthy in that it was enforced against a second-generation owner (apparently deemed to have consented to the easement by purchasing with notice), it yielded a significant financial loss for the owner, and it resulted in the destruction of a residence, often an area of special protection for American courts. ${ }^{175}$

When the plain meaning of the easement language is not clear, care must be used in considering extrinsic evidence when successors are involved. In one case, the court had to decide whether the consolidation of the several lots into a new record lot would violate a conservation easement provision barring "subdivision" of lots that had been granted by a preceding owner to a nonprofit organization. ${ }^{176}$ The current owners argued that "subdivide" has a plain and ordinary meaning of cutting a larger tract of land into smaller pieces. The court stated that the jurisdiction followed an "objective" view of interpretation and written language would control, but that the context in which the word was used shapes its meaning. Thus, the court held that "subdivide" is susceptible to different meanings than the owner's asserted dictionary definition, and thus ambiguous. To resolve the ambiguity, the court looked to the local planning regulation that defined "subdivision" to include assembly of lots finding that "the parties knew or should have known the meaning of 'subdivide' in real estate at the time the Easement was created." 177 Presumably, "parties" referred to the original parties to the easement. The real question should have been whether the successors knew or could have known the terms of the regulation. Assuming that they could have (for example, if the statutory definition of subdivide remained the same at the time of purchase, they should have been aware of the broader meaning of "subdivide" in real estate transactions), then the result in the case is correct though the articulation (that is, "[original] parties") needs clarifying.

Closely interpreting conservation easements serves the goals of freedom of contract while not saddling buyers with unknown or unknowable restrictions. In this way, parties can freely bargain - and count on enforcement of their deals. At the same time, the burden is on them to make clear the extent of the restriction so that future owners will not be caught unaware, thus serving the spirit of the antirestrictions policy.

\section{Principle IV: Achieving Flexibility Through Expanded Modification and Termination Doctrines}

The law of covenants provides several doctrines that may be useful in addressing perpetual conservation easements. Again, note the irony that despite the

${ }^{175}$ See John Leland Mechem, The Peasant in His Cottage: Some Comments on the Relative Hardship Doctrine of Equity, 28 S. CAL. L. REV. 139, 144 (1955) ("[T] he basic concept, that private ownership of a dwelling house is still the most inviolable of all property rights.").

${ }^{176}$ Sagalyn v. Found. for the Pres. of Historic Georgetown, 691 A.2d 107, 108-09 (D.C. App. 1997).

${ }^{177}$ Id. at 112 . 
easement misnomer, the law of covenants, not easements, has developed doctrines to deal with outmoded negative restrictions on land. While traditional doctrines of changed conditions, cy pres, and relative hardship may provide some assistance in dealing with outmoded conservation easements, a revitalized doctrine barring enforcement of covenants violating public policy may provide the most powerful tool.

\section{Changed Conditions}

First, the doctrine of changed conditions provides that the courts will not enforce a covenant if the conditions since it was created have so changed that enforcement will not bring its intended benefits. ${ }^{178} \mathrm{~A}$ typical case involves a subdivision burdened by residential building and use restrictions, with the goal of creating a quiet living situation. Internal changes, such as a strong pattern of nonenforcement against breaches or a governmental taking of a large portion of the subdivision, may make it impossible to achieve the original residential goal. ${ }^{179}$ The doctrine of changed conditions would bar enforcement of the covenant against a new violator of the covenant.

Changed conditions theory could be applied to terminate a conservation easement. ${ }^{180}$ For example, when surrounding pollution and development becomes so great that a conservation easement on a property to protect habitat for migrating species no longer can accomplish its purpose, or a historic stand of trees is destroyed by fire. These will not be easy cases to make, however. Proponents of the easement will argue that any open space is valuable and especially necessary when surrounding conditions have worsened. ${ }^{181}$ Moreover, the Third Restatement of Property has a specific provision that prohibits the application of changed conditions to private conservation servitudes unless certain conditions are met. ${ }^{182}$ It provides that if the particular conservation purpose becomes impracticable, then it should be modified for other conservation purposes based on the cy pres doctrine; and if it can no longer accomplish any conservation purpose, it may be terminated with damages and restitution. ${ }^{183}$

Most importantly, though, the changed conditions doctrine, even if applied by the courts, does not address the fundamental public policy choices raised in this Article. The changed conditions theory provides a means to deal with covenants that are obsolete and serve little or none of their original purpose. It does not, however, provide a mechanism for balancing a strong public interest in a new use

${ }^{178}$ KORNGOLD, supra note 52 , at 453-455.

${ }^{179} \mathrm{Id}$. at $456-462$.

${ }^{180}$ Korngold, supra note 7, at 485-486. See Susan F. French, Perpetual Trusts, Conservation Easements, and the Problem of the Future, 27 CARdozo L. REV. 2523, 2523-24 (2006); Jeffrey A. Blackie, Note, Conservation Easements and the Doctrine of Changed Conditions, 40 HASTINGS L.J. 1187, 1188 (1989).

${ }_{181}$ Korngold, supra note 7, at 485.

${ }^{182}$ Restatement (ThiRd) OF Prop. (SERVITUdes) $\S 7.11$ (2000).

${ }^{183}$ Id. § 7.11(1), (2). 
for the land (perhaps for necessary industrial development, affordable housing, or health care facilities) against the conservation value exemplified by the easement held by a private organization.

\section{CyPres}

The doctrine of cy pres, a rule of construction borrowed from charitable trusts that instructs that the terms of a will should be interpreted to conform to the will of the testator when literal construction is impracticable or impossible, can provide an important method to adjust a conservation easement where the particular purpose of the easement has likewise become impossible or impracticable. ${ }^{184}$ Applying the doctrine, the court will adapt the easement to another conservation purpose compatible with the overall conservation goal. ${ }^{185}$ This might even mean the sale of the easement and the transfer of the conservation purpose to another parcel of land. ${ }^{186} \mathrm{Cy}$ pres brings some desirable suppleness into perpetual land interests, and should be embraced by the courts. But it too does not provide a solution to the concerns raised in this Article. Indeed, the term "cy pres" comes from the "Norman French phrase cy près comme possible, meaning 'as nearly as possible." ${ }^{\prime 187}$ The doctrine contemplates incremental changes from the original instrument, not the broader deviations to serve the public interest that may be required under the analysis suggested in this Article.

\section{Doctrine of Relative Hardship}

The doctrine of relative hardship may provide some support for a court attempting to balance the public interest in relaxing a conservation easement against the holder's attempt to strictly enforce the restriction, though some shifts in judicial attitude would be required to make this possible. The relative hardship doctrine is quite amorphous and stated in a variety of ways by the courts. A common formulation is that a court will not specifically enforce a covenant and limit the remedy to damages if the harm of the injunction will be disproportionate to the benefits of specific enforcement. ${ }^{188}$

Despite its elasticity, the relative hardship doctrine as presently conceived cannot be easily used to deny enforcement of a conservation easement due to public concerns because the current formulations of the relative hardship doctrine do not include an express consideration of the public interest. ${ }^{189}$ Rather, the courts describe relative hardship as a matter between two individuals, sometimes even

184 See id. § 7.11(1); Nancy A. McLaughlin, Amending Perpetual Conservation Easements: A Case Study of the Myrtle Grove Controversy, 40 U. RICH. L. REV. 1031, 1040 (2006); McLaughlin, supra note 7.

${ }^{185}$ RESTATEMENT (THIRD) OF PROP. (SERVITUdES) $\S 7.1$, cmt. b.

${ }^{186}$ See McLaughlin, supra note 7, at 436.

187 Jesse DuKeminiER ET AL., WILLS, TRUSTS, AND EsTATES 738 (7th ed. 2005).

${ }^{188}$ For a complete discussion of the rule, see KORNGOLD, supra note 52, at 462-470.

${ }^{189}$ Id. at 468 . 
specifically rejecting the public factor. ${ }^{190}$ The relative hardship doctrine lacks a stated dimension of the societal interest, unlike the Second Restatement of Torts, which asserts that "[ $[t]$ he interests of third persons and the public are factors to be considered in determining the appropriateness of an injunction against tort.",191 This broad standard of the Second Restatement of Torts is reflected in nuisance cases, giving courts significant latitude to balance competing interests, which is not found in the relative hardship doctrine. ${ }^{192}$

The relative hardship doctrine can become a meaningful and legitimate tool to balance the public interest against conservation values if two shifts in judicial attitude and doctrine occur. First, currently courts routinely state that covenants (which would include conservation easements) are automatically enforceable by injunction even though no irreparable harm or monetary loss can be shown. ${ }^{193}$ The reality, though, is that courts would need to remember that while injunctions are generally awarded, they are not and need not be granted in every case. Injunctions are a doctrine of equity and can be refused in a covenant action based on the equities of the situation. ${ }^{194}$ Rote repetition of the typical result (that is, an injunction) does not make it a universal rule; rather, it may serve to cloud the law and confuse courts and actors by writing the flexibility of the courts out of the equation.

Second, the courts and legislatures need to expand the doctrine of relative hardship to include express consideration of the public interest in the requested injunction. Thus, in a conservation easement injunction case, the court would have to consider the public's interest in specific enforcement and not only the positions of the conservation organization and the servient owner. If the court denied an injunction and awarded damages, the conservation organization could use such funds on another parcel consistent with the conservation goals of the original easement. This would maintain the donor's intent where the easement had been contributed, prevent the loss of the tax subsidy, and be consistent with the organization's mission and governing documents.

${ }^{190}$ See, e.g., Wier v. Isenberg, 420 N.E.2d 790, 793 (Ill. App. Ct. 1981) ("[A] court does not balance the equities as it would in an ordinary nuisance case or in a request for rezoning."); Evangelical Lutheran Church of the Ascension of Snyder v. Sahlem, 172 N.E. 455,457 (N.Y. 1930) ("Neither at law nor in equity is it written that a license has been granted to religious corporations, by reason of the high purpose of their being, to set covenants at naught.").

${ }^{191}$ Restatement (SECOND) OF TORTS $§ 942$ (1977). Restatement (ThiRd) OF Prop. (SERVITUDES) $\S 8.3(1)$ (2000) comment (e) now suggests that courts should consider the costs and benefits to the parties, third parties, and the public when forming remedies for covenant violation.

192 See, e.g., Boomer v. Atl. Cement Co., 257 N.E.2d 870, 872 (N.Y. 1970) (denying injunction and awarding one-time damages for nuisance caused in the past and future by dust from cement plant).

${ }^{193}$ KORNGOLD, supra note 52, at 434.

${ }^{194}$ For example, laches and unclean hands by the applicant. See id. at $450-453$. 


\section{Covenants Violating Public Policy}

Courts often state that they will not enforce covenants that violate public policy. ${ }^{195}$ Many of these declarations are dicta and there are few decisions where courts actually void a covenant on public policy grounds. ${ }^{196}$ One line of cases, though, could be relied upon by a court seeking to modify or terminate a conservation easement that conflicts with fundamental local land use policy. These cases found a public policy, clearly articulated in state statutes and regulations, favoring group homes for the disabled rather than institutional care. These courts relied on this public policy to refuse enforcement of private covenants that barred group homes, ${ }^{197}$ despite the countervailing public policy favoring property rights and residential subdivision developments. ${ }^{198}$

Conservation easements, in contrast, do not violate public policy but rather are favored by public policy as evidenced by express, statutory authorization of these interests. As a general matter, conservation easements are beneficial and should be enforced. There may be, however, rare occasions where another major, clearly articulated state policy-such as one favoring economic development, affordable housing, or public planning-is threatened by the continued enforcement of the original conservation easement. In such a situation, the court would have to balance the competing public interests, perhaps to the disfavor of conservation goals, when deciding on the enforcement or modification of a particular conservation easement. This would be a legitimate expression of the principle that courts should not enforce covenants that violate public policy.

\section{Termination and the $I R C$}

Judicial application of changed conditions, expansion of the relative hardship doctrine, and a prohibition on covenants violating public policy would have federal tax ramifications in the case of a donated easement. The IRS regulations seek to prevent a revenue loss in the event that "a subsequent unexpected change in the conditions surrounding the property... makes impossible or impractical the continued use of the property for conservation purposes." 199 The original deduction by the donor will not be affected as long as the restrictions are extinguished in a judicial proceeding and the nonprofit's portion of the proceeds are used in a

$195 \mathrm{Id}$. at 397.

${ }^{196} I d$. at $397-98$.

${ }^{197}$ See, e.g., Welsch v. Goswick, 181 Cal. Rptr. 703, 708 (Cal. Ct. App. 1982); Sate v. District Court, 609 P.2d 245, 247-48 (Mont. 1980); Crane Neck Ass'n, Inc. v. New York City/Long Island County Servs. Group, 460 N.E.2d 1336, 1339 (N.Y. 1984), cert. denied, 469 U.S. 804 (1984). But see Mills v. Kubena, 685 S.W.2d 395, 398-99 (Tex. App. 1985); Mains Farm Homeowners Ass'n v. Worthington, 824 P.2d 495, 499 (Wash. Ct. App. 1992), aff'd, 854 P.2d 1072 (Wash. 1993).

${ }_{198}$ See Gerald Korngold, Resolving the Flaws of Residential Servitudes and Owners Associations: For Reformation Not Termination, 1990 WIS. L. REV. 513, 518.

${ }^{199} 26$ C.F.R. $\S 1.170 \mathrm{~A}-14(\mathrm{~g})(6)(\mathrm{i})(2007)$. 
manner consistent with the conservation purpose of the original easement. While the regulation specifically contemplates termination due to changed conditions, the theory of the provision - prevention of revenue loss-would make it similarly applicable in situations of termination or rejection of specific enforcement under the relative hardship doctrine or the prohibition against violation of public policy.

\section{E. Principle V: Preserving the Public's Power of Eminent Domain}

Like other covenants ${ }^{200}$ (and, for that matter, easements ${ }^{201}$ ), private conservation easements are subject to being taken via eminent domain. ${ }^{202}$ Various conservation easement statutes even expressly provide for taking by eminent domain. ${ }^{203}$ With appurtenant covenants, compensation is usually the difference in value of the benefited parcel with and without the covenant. ${ }^{204}$ With covenants in gross, such as conservation restrictions, there is no benefited land so an alternative measure is used: the difference in the value of the burdened land with and without the covenant. ${ }^{205}$ This alternative, though, focuses exclusively on the burdened land and may not capture the ecological value and benefit of the conservation easement to the nonprofit easement owner. ${ }^{206}$

\footnotetext{
${ }^{200}$ See KORNGOLD, supra note 52, at 473-476.

${ }^{201}$ See id. at $268-71$.
}

202 See Hartford Nat'l Bank \& Trust Co. v. Redev. Agency of City of Bristol, 321 A.2d 469, 473 (Conn. 1975) (requiring compensation for eminent domain action that invalidated an in gross building restriction, much like a conservation easement); BYERS \& PONTE, supra note 16 , at 191-92.

${ }^{203}$ See, e.g., N.Y. ENVTL. CONSERV. LAW § 49-0307(3)(b) (McKinney Supp. 2007); N.C. GeN. STAT. § 121-36(c) (2005); VA. CODE ANN. § 10.1-1010(F) (2006). See UNIF. CONSERVATION EASEMENT ACT $\S 2$ (a), 12 U.L.A. 170 (1996) (providing that a conservation easement can be "terminated" like other "easements"); id. prefatory note, 12 U.L.A. 166 ("The Act neither limits nor enlarges the power of eminent domain . ...").

${ }^{204}$ See KORNGOLD, supra note 52, at 475.

${ }^{205} \mathrm{Id}$. The measure is the same when calculating the value of a (true) easement in gross for taking purposes. See id. at 270. See generally, Gregory Bialecki, What Must the Taking Authority Pay for Land Subject to a Conservation Easement?, THE BACK FORTY, July/Aug. 1990, at 6 (stating the valuation procedure for conservation easements should be the same as covenants in gross); Gregory Bialecki, Eminent Domain Takings of Land Subject to Conservation Easements, THE BACK FORTY, Sept. 1990, at 8-9 (describing the method of valuation for "easement in gross in the context of eminent domain proceedings" and its potential application to valuing conservation easements).

206 Section $170(\mathrm{~h})$ and the accompanying IRS Regulations do not provide for distribution of proceeds on condemnation. While not required by IRS regulations, good stewardship and corporate fiduciary norms would appear to require the organization to invest the proceeds from the taking in new conservation activities. One would think that there would be a requirement for the proceeds to be used for conservation purposes, as in a case of a court approved voluntary transfer due to impracticability or impossibility. See 26 C.F.R. $\S 1.170 \mathrm{~A}-14$ (c)(2) (2007). 
It is essential that government have the ability to assert its eminent domain power to take conservation easements for compensation. This will allow communities to inject flexibility into past plans imposed on them by private organizations and to address through a public process the new communal challenges that inevitably will develop in the future. Eminent domain has long provided the collective with a necessary tool to remedy errors of the past. The state's ability to bring an eminent domain action also offsets the landowner's monopoly power over her land, and thus facilitates bargaining between the government and the owner to resolve the issue. Eminent domain power, wellexercised and under rigorous judicial supervision, is essential to current and future generations.

This important governmental power has been under siege, however, since the decision of the Supreme Court in Kelo v. City of New London ${ }^{207}$ Kelo involved a comprehensive redevelopment plan on ninety waterfront acres to create new commercial, retail, residential, and recreational space. The plan had been through an extensive public process and received governmental approval. The purpose of the plan was to revitalize the declining economic condition of the city. Petitioners, owners of some residential properties, challenged the attempt to take their land pursuant to the plan, claiming that there was no "public use" under the Fifth Amendment. Rather, they argued that the land would be owned and used by private parties after the redevelopment and that economic development was not a legitimate public use for which a taking could be made.

The Court rejected the Petitioners' claims. It found that the area did not need to be "blighted" to find a public use and that the local legislative determination to implement "economic rejuvenation" was entitled to deference. Moreover, while the land ultimately ended up in the hands of private parties, Kelo did not involve the improper situation of government using its taking power in an ad hoc manner to favor one individual owner over another. Rather, the entire public benefited by the comprehensive development and plan in Kelo.

There has been a huge and ongoing popular, legal, and scholarly backlash against the Kelo decision. Many state legislatures have passed restrictions on eminent domain power of state and local government, often barring takings for economic development purposes. ${ }^{208}$ Voters in November 2006 approved similar

${ }^{207} 545$ U.S. 469 (2005).

${ }^{208}$ See, e.g., AlASKa STAT. $\S 09.55 .240$ (d) (2006) (prohibiting the use of eminent domain for the purpose of economic development); COLO. REV. STAT. $\S 38-1-107$ (b) (2006) (prohibiting eminent domain for economic and tax revenue enhancement and requiring proof of blight); IDAHO CODE ANN. § 7-701A(2)(a) (2004 \& Supp. 2007) (prohibiting use of eminent domain where it is merely a pretext for the transfer of the property to a private party). For a list of various state enactments, see the website of the American Planning Association, http://www.planning.org/legislation/eminentdomain/ edlegislation.htm. See also Marcilynn A. Burke, Much Ado About Nothing: Kelo v. City of New London, Babbitt v. Sweet Home, and Other Tales from the Supreme Court, 75 U. CInN. L. Rev. 663, 699-702 (2006); Donald E. Sanders \& Patricia Pattison, The Aftermath of Kelo, 34 REAL EST. L.J. 157, 164-70 (2005). 
ballot measures. ${ }^{209}$ State courts have rejected the Kelo interpretation by reading their state constitutions to bar takings for economic development or unless the area is blighted. ${ }^{210}$ Popular press and scholarly opinion have generally blasted Kelo. ${ }^{211}$

Contrary to the critics, Kelo was decided correctly. As a matter of constitutional law, the Court provided plausible support for its decision. ${ }^{212}$ As a matter of public policy, the Court made the right choice, providing government with the tool necessary to meet changing needs and correct the errors of the past. The alternative would be a frozen land utilization pattern, with ill effects for the present and future citizenry. Conservation easements provide an important illustration. Eminent domain is necessary to address those rare situations when an essential public need-for example, economic development or affordable housing - cannot go forward because of a prior privately made arrangement. It allows for a public process to vindicate communal values and protect flexibility. Such a utilitarian argument may be rejected by pure property rights proponents, but the Fifth Amendment expressly contemplates limitations on private property based on a notion of the social contract.

This does not mean that the government should use eminent domain cavalierly to take conservation easements or any other private property rights. Takings should involve careful planning, deliberations, and public debate. The constitutional protections outlined in Kelo and procedural safeguards must be followed. Given the severity of the action and the fact that government must pay "just compensation," takings should be a rare last resort by government.

${ }^{209}$ GA. CONST. art. IX, $\S 2$, ๆ VII (passed, set out in GA. H.R. 1306); S.C. ConST. art. XIV, $\S 5$ (passed, set out in S.C. S.B. 1030).

${ }_{210}$ See, e.g., Centene Plaza Redev. Corp. v. Mint Props., 225 S.W.3d 431, 435 n.3 (Mo. 2007) (holding that Missouri Constitution prevents taking primarily for benefit of another private party); Gallenthin Realty Dev., Inc. v. Borough of Paulsboro, 924 A.2d 447, 469 (N.J. 2007) (stating that property that was "not fully productive" was not "blighted"); Norwood v. Horney, 853 N.E.2d 1115, 1140-41 (Ohio 2006) (holding that an economic benefit alone is insufficient to satisfy the public use requirement).

${ }^{211}$ See, e.g., Ilya Somin \& Jonathan H. Adler, The Green Costs of Kelo: Economic Development Takings and Environmental Protection, 84 WASH. U. L.Q. 623, 638 (2006) (arguing that economic development takings may cause environmental harm); see also Richard A. Epstein, Kelo: An American Original, 8 GREEN BAG 2d 355, 361 (2005); Gideon Kanner, The Public Use Clause: Constitutional Mandate or "Horatory Fluff"?, 33 PEPP. L. REV. 335, 336 (2006); Daniel B. Kelly, The "Public Use" Requirement in Eminent Domain: A Rationale Based on Secret Purchases and Private Influence, 92 CORNELL L. REV. 1, 62 (2006); John M. Broder, States Curbing Right to Seize Private Homes, N.Y. TIMES, Feb. 21, 2006, at A1; Martin Kasindorf, Voters Get a Say on Land Rights, USA ToDAY, Sept. 24, 2006, at A1; Carla T. Main, The "Blight" Excuse, WALl ST. J., June 30, 2005, at A11; Editorial, Thoy Paved Paradise, Wall ST. J., June 30, 2005, at A12. There are few scholarly articles supporting Kelo. One noteworthy exception is Abraham Bell \& Gideon Parchomovsky, The Usefulness of Public Use, 106 CoLUM. L. REV. 1412 (2006).

${ }^{212}$ See, e.g., Berman v. Parker, 348 U.S. 26, 33-35 (1954) (stating that the concept of public welfare is broad and inclusive as the values it represents are "spiritual as well as physical, aesthetic as well as monetary"). 


\section{CONCLUSION}

Private conservation easements bring substantial benefits as we seek to preserve for future generations the ecological and natural values of land against the pressures of development. At the same time, the perpetual nature, rigidity, and nonpublic attributes of these interests present challenges for present and future generations. The advantages of private conservation easements can be enhanced by implementing the five principles suggested in this Article that will result in market benefits, increased flexibility, and community participation. 